\title{
A kortárs képelemzés kognitív szempontú megközelítése
}

\author{
VirÁg Ágnes \\ Eötvös Loránd Tudományegyetem, Bölcsészettudományi Kar, doktorandusz
}

\begin{abstract}
Miközben egy reklámot, vagy egy filmjelenetet nézünk, sokszor az elvont dolgokat konkrétabb fogalmakon keresztül ragadjuk meg, amit vizsgálhatunk a kognitiv nyelvészet eszközeivel (Lakoff és Johnson, 1980; Forceville és Urios-Aparisi, 2009). A tanulmány olyan kognitivv szempontú módszertant mutat be, amellyel elemezhetöek a kortárs mütárgyak és a hozzájuk kapcsolódó müvészettörténeti dokumentumok. A módszer a vizuális és a verbális módokra fókuszál, többek között magyarázatot ad arra, hogyan lehetséges, hogy egy tárgynak több jelentése is lehet. Összehasonlithatóvá teszi a hétköznapi és az egyedi jelentésalkotást, a globális és a lokális kontextus által meghatározott jelentéseket. A módszertant Baglyas Erika "Jó elöre gondoljon a jövőjére!" címü installációjának elemzése szemlélteti.
\end{abstract}

Kulcsszavak: kognitív nyelvészet, multimodalitás, tartalomelemző módszertan, kortárs képzőmüvészet

Kognitív folyamatok a vizuális módban

\section{Bevezetés}

Különböző tudományterületek - a művészettörténet, a multimodalitás-elmélet, a kognitív nyelvészet és a kognitív pszichológia - foglalkoznak vizuális elemzési módszerekkel. Míg a művészettörténészek célja a mütárgy, vagy inkább a jelenség elhelyezése és értelmezése nagyobb összefüggésrendszerekben, addig a pszichológusok a pszichoanalitikai módszereket gyógyításra használják. A kognitív nyelvészek vizuális elemzései azt tárják fel, hogyan gondolkozik az ember, amikor létrehozza, vagy befogadja a vizuális ingereket.

A tanulmányban célom egy olyan rugalmas módszertani keret meghatározása volt, amelylyel elemezhetőek a kortárs műalkotások. A tartalomelemzés során elsősorban a mütárgyhoz kapcsolódó értelmező gondolkodás érdekelt. Feltételeztem, hogy amikor a szemlélő egy konkrét mütárgyat néz és az valamilyen oknál fogva megragadja őt, akkor a néző elkezdi továbbgondolni és értelmezni a tárgyat. Az aktus során akaratlanul is kognitív folyamatokat hajt végre, amelyek között vannak metaforikusak és metonimikusak. A metaforikus folyama- tok során a látott jelenséget azonosítjuk egy vagy több elvont dologgal, folyamattal. Például egy ház alakú perselyt (1. ábra) látva az egyik szemlélő azt mondta: „a szegényeknek segítségre van szükségük ahhoz, hogy valahol lakni tudjanak." Érzékelhető, hogy a befogadó a házat az emberi élet céljával azonosította, míg az adakozást a segítséggel hozta összefüggésbe. A metonimikus látásmód érvényesül viszont abban a helyettesitó folyamatban, amikor ugyanaz a szemlélő azt állítja, hogy „ez az egyszerü puritán fehér forma jelképezi a szegénységet és a szerény életmódot." A forma és a kivitelezés a társadalmi pozíció és a hozzá kapcsolódó életmód helyett áll. Megfigyelhető, hogy a metaforikus és a metonimikus folyamatok szorosan összekapcsolódnak a természetes gondolkodás során.

A módszertani dolgozat három részből áll. Az első fejezetben definiálom a fogalmi metaforát és a fogalmi metonímiát, amelyeket kognitív nyelvészeti keretben értelmezek. A második részben azoknak a korábbi módszertanoknak a lényegét mutatom be, amelyek befolyásoltak az új módszer kialakításában. A harmadik, gyakorlati részben bemutatom az általam alkalmazott módszertant és részlete- 


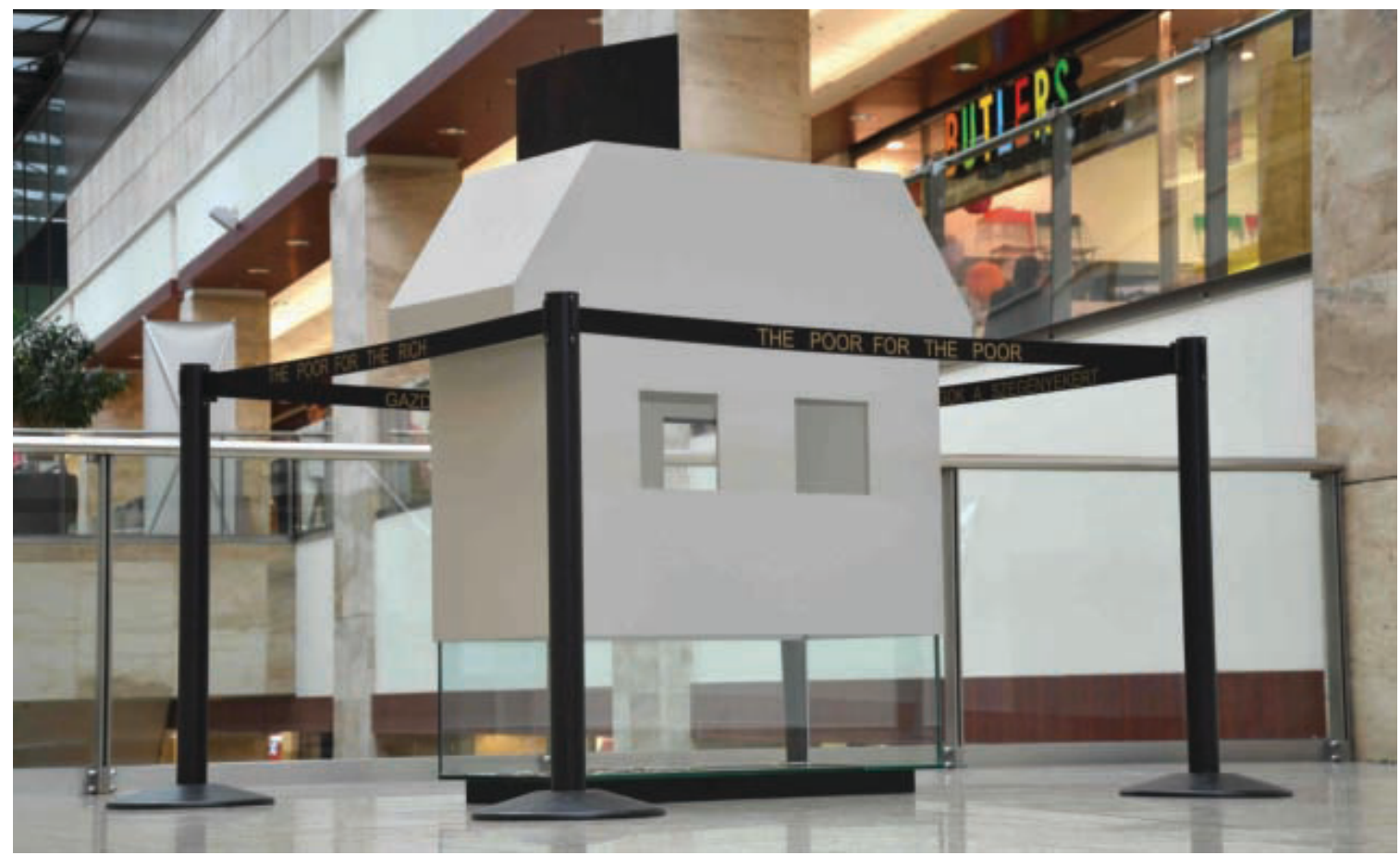

1. ábra: Baglyas Erika: „Jó előre gondoljon a jövőjére!”, 2013.

sen elemzem Baglyas Erika Jó elöre gondoljon a jövőjére! (2013) című installációját. A tanulmány befejezéseként azt emelem ki, hogy a különböző kontextusok hogyan járulnak hozzá a tárgy értelmezéséhez, valamint összegzem a módszer előnyeit, hátrányait és eredményeit.

\section{A metafora}

A kognitív nyelvészek George Lakoff és Mark Johnson (1980) után abban egyetértenek, hogy az emberi gondolkodás fogalmak segítségével történik és a folyamatban jelentős a testesültség (embodiment) szerepe. A testesültség arra utal, hogy az ember gondolkodását saját testéhez és testének a környezetéhez füződő viszonya alapvetően meghatározza. Például a testünket tartályként értelmezzük, amikor azt mondjuk, hogy „gombóc van a gyomrunkban." A testünk abszurd, irreális viszonyba kerül a környezetünkkel, amikor ujjongva „a felhők fölött járunk”. Az elvont jelenségeket, cselekedeteket, érzelmeket, de akár a nehezebben érthető, nem teljesen világos hétköznapi dolgokat is sokszor konkrétabb dolgokon keresztül, vagy analógiák segítségével próbáljuk meg értelmezni. A fent említett metaforikus kijelentések alapját a fogalmi metaforák jelentik, amelyek forrásés céltartományból állak. Például a „gombóc van a gyomromban" kifejezés arra utal, hogy a TEST céltartományt a TARTÁLY forrástartomány, míg az ÉRZELEM céltartományt a TARTÁLYBAN LÉVŐ TÁRGY forrástartomány segítségével értelmezzük. Megállapíthatók A TEST TARTÁLY és AZ ÉRZELEM (A TARTÁLYBAN LÉVŐ) TÁRGY fogalmi metaforák. Ugyanezek a fogalmi metaforák más metaforikus kifejezésben is megnyilvánulhatnak. Gondoljunk például a „kő nehezedik a szívére” kijelentésre! A metaforikus folyamat során a forrástartomány bizonyos elemeit a céltartomány bizonyos elemeivel feleltetjük meg (Lakoff és Johnson, 1980; Kövecses és Benczes, 2010). Amikor a testet tartályként értelmezzük, akkor a tartály alapszerkezetét a test felépítésével kapcsoljuk össze. Megfeleltetések jönnek létre a tartály belseje és a test belseje, a külső tér és a testen kívüli tér, a tartály fala és a testet borító bőrszövet között. Mindkét korábbi példában, a „gombóc” és a „kő" esetében is a test belsejére és a benne lévő idegen testre fókuszálunk. 
A kortárs képelemzés kognitív szempontú megközelítése

Lakoff és Johnson hangsúlyozták azt, hogy a fogalmi metaforák nem a nyelvhez, hanem a gondolkodáshoz és a cselekedeteinkhez kötöttek. Kijelentésükből következik, hogy a fogalmi metaforák vizuális és más módokban, valamint eltérő müfajokban is jelen vannak. Charles Forceville 1988-ban kezdett el foglalkozni a vizuális módban, szürrealista festményeken megjelenő metaforákkal. Metaforatipológiájában megkülönböztette a monomodális $(1988,1996)$ és a multimodális metaforákat (1996, 2009). A monomodális metaforák mindkét tartománya, a forrás- és a céltartomány is ugyanabban a módban jelenik meg. Ha a két tartomány vizuális, akkor a metafora piktorális. A piktorális metaforáknak négy típusa van: ez a hibrid, az integrált, a kontextuális metafora és a képi hasonlat ${ }^{1}$. Forceville egy fiktív animációval illusztrálta a piktorális metaforát: egy macska elefántormánnyal sétál (A MACSKA ELEFÁNT, Forceville és Urios-Aparisi, 2009). Ez a hibrid típusba tartozik, vagyis két össze nem illő tartomány, a macska teste és az elefántormány forr össze egy testben. A hibridben érvényesül az összeférhetetlenség és az egyterűség elve, de a nyelvész szerint ez nem prototipikus piktorális metafora. Azt állítja, hogy hibridek ritkák a reklámokban, mert azok készítői nem szeretnék a terméket félreérthető, csonka vagy módosult formában bemutatni. A reklámokban

\footnotetext{
${ }^{1}$ Az integrált metaforákban a forrástartomány vizuálisan érzékelhető, de jól illeszkedik a céltartományhoz és nem érezhető anomália. Forceville példája a SENSEO KÁVÉFŐzŐ SZOLGA metafora, amikor a reklámban egy enyhén előrehajló formatervezett kávéfőzőt látunk. Az alak felidézi a felszolgálással együtt járó testtartást. A kontextuális metaforában a vizuálisan ábrázolt céltartományt a vizuális kontextus módosítja. Egy reklámban egy doboz cigaretta a szappan helyén jelenik meg (A CIGARETTA SZAPPAN) egy fürdőszobában. Forceville értelmezésében a megfeleltetett tulajdonság az, hogy „kéznél van”, amelyet a fürdőszobai környezet hív életre. A piktorális hasonlatokban a forrás- és a céltartomány külön entitásként szerepel egymás mellett, de közelségük révén összekapcsolódnak. A nyelvész szerint ilyen az a korsó sör is, ami mellett a reklámban a pisai ferdetorony tünik fel (A SÖR A PISAI FERDE TORONY). A két tárgyat összekapcsoló tulajdonság a „nemzeti büszkeség”, ami középpontba kerül a két nevezetesség kapcsán.
}

gyakoriak az integrált metaforák, ahol nincs összeférhetetlenség és a kontextuális metaforák, ahol pedig nincs egyterüség.

Forceville multimodális metaforáknak nevezi azokat a metaforákat, amelyeknek a forrás- és a céltartománya jellemzően különböző módban manifesztálódik (Forceville és Urios-Aparisi, 2009). Például, ha az elefántormányos macskát látva egy másik macska rémülten felkiált: „Te jó ég, egy elefánt!” Akkor láthatjuk és hallhatjuk, hogy A MACSKA ELEFÁNT metafora verbálisan is megerősítést nyer. Ebben az esetben verbo-piktorális metaforáról beszélhetünk, amelyet Forceville az egyik leggyakoribb multimodális metaforatípusnak tart.

A képzőművészeti alkotások elemzésénél érdemes figyelembe venni azt, hogy milyen módok játszanak szerepet az értelmezés folyamatában. Az érzékelésben ugyanis többféle mód - hangzó, vizuális, verbális - is megjelenhet, amik módosíthatják vagy erősíthetik egymást. Akár képzőművészeti katalógusról, akár múzeumi környezetről van szó a müvészettörténészek és a kurátorok irányítják a befogadást és azt gyakran feliratokkal segítik. Az értelmezést maguk a szakemberek is verbális és vizuális források tanulmányozásával végzik. A multimodalitás a képzőművészeti alkotások gyakori jellemzője.

\section{A metonímia}

Kognitív nyelvészeti paradigmában a metonimikus folyamatok a metaforához hasonlóan fogalmakhoz kapcsolódnak, de attól eltérően ugyanazon a tartományon belüli érintkezésen alapulnak. A metonímiák rész-egész, egészrész és rész-rész viszonyokban valósulnak meg. Például „az egész ház talpon van” kifejezésben A HÁz A LAKÓK HELYETT ÁLL, vagyis az egész a rész helyett áll.

Charles Forceville Lakoff és Johnson (1980) után utal arra, hogy a vizuális művészetekben gyakoriak a metonimikus folyamatok. Az értelmezés során jelentős szerepet játszanak a vizuális tartományhoz kapcsolódó metonimikus konnotációk. A színek, a formák, az arányok, a technika metonimikus folyamatok 
részét képezhetik. Forceville fiktív példája szerint a TOLL KARD metafora esetén más értelmet nyer, ha az ember egy kis énekesmadár, egy páva vagy egy ragadozó madár tollát fogja a kezében kardként. A toll külső jegyei alapján eltérő metonimikus alapot teremt a metaforához. A kis énekesmadár tolla állhat a törékenység, míg a páva a büszkeség, vagy a hiúság helyett. A ragadozó madár tolla pedig utalhat az állat éber, gyors tulajdonságaira, ami a TOLL KARD metaforán keresztül a tollat kezében tartó ember jellemzőjévé válik.

Forceville feltételezi, hogy a képzőművészetben ritkák a piktorális metaforák, mivel a művészet nem olyan direkt, mint a reklámok - leszámítva a propagandaplakátokat. A képzőművészetre szerinte sokkal inkább jellemzőek a szimbólumok és a metonímiát a szimbólumok egyik fajtájának tartja. Példaként egy olyan képet említ, amin egy kézfejet látunk töviskoszorút idéző karkötővel. Ez Forceville értelmezésében a következőképpen írható le: A TÖvISKOSzORÚ KARKÖTŐ, amelyben A TÖVISKOSZORÚ FORMA A SZENVEDÉS HELYETT ÁLL (Forceville, 2010). Szabó Réka doktori disszertációjában kifejti, hogy a szimbólumokat nem tudjuk teljes egészében megragadni. Az előbb említett töviskoszorú például a krisztusi szenvedés mellett Krisztus teljes élettörténetét képes felidézni, így a feltámadást is, de az a vérző kézfej láttán nem aktivizálódik. Szabó szerint, ami a szimbólumokból megragadható, azok maguk a fogalmi metaforák és fogalmi metonímiák, de a szimbólumnak mindig marad nem tudatosítható része (Szabó, 2014. 109. o.).

\section{Kognitív szempontú vizuális elemzések}

A kognitív szempontú képelemzések nem mondanak ellent a művészettörténeti interpretációs módszereknek, például Panofsky (1955/84) háromszintű elemzési modelljének²,

\footnotetext{
${ }^{2}$ Az első preikonografikus szinten a megismerés tárgya a jelenségértelem. A jelenség leírásához a mindennapi érzéki tapasztalataink szükségesek. Panofsky egy hétköznapi példával illusztrálta elméletét: egy alak megemeli a fején lévő kalapot. A második az ikonografikus szint, amelyben a jelentésértelem megragadására törekszünk. A
}

hiszen az érzékelhető és a nem érzékelhető tartalmak megkülönböztetésén alapulnak. A kutatás szempontjából elválasztják a percepció és a tudatosítás (appercepció) folyamatát. Az érzékeléshez kapcsolódóan Panofsky preikonografikus elemzést végez, Forceville leírást készít, Šorm és Steen, valamint Kuuva a percepció fogalmán keresztül ragadják meg a vizuális megtapasztalásnak ezt a fázisát.

A vizuális művészet értelmezőjének a konkrét mütárgy tanulmányozása mellett gyakran egy korábbi magyarázatot kell felülvizsgálnia és újragondolnia. Kétféle problémával állunk szemben: az egyik a kép értelmezése (Panofsky, 1955/84; Forceville, 1988-2015, Isaeva és Mishlanova, 2015), a másik a kép verbális értelmezésének magyarázata (Šorm és Steen, 2013; Kuuva, 2007). Az interpretáció folyamatát a művészettörténész olyan profeszszionális munkának tartja, amelyben további objektív tudáselemeket hív segítségül az ikonografikus és az ikonológiai elemzések során, alapvető célja a műtárgy minél szélesebb körü kontextualizálása. Az értelmezést a kognitív nyelvészek a konceptualizáció folyamatának nevezik, utalva ezzel arra, hogy alapvetően fogalmak és fogalmi rendszerek segítségével gondolkodunk, a módszerek során céljuk a fogalmi metaforák meghatározása volt. A pszichológusok ugyanezt a folyamatot a tudatosítás névvel illetik, amelyben a szemlélő nem érzékelhető információtartalmakkal kapcsolja össze az érzékelhető tartalmakat, céljuk a vizuális befogadás folyamatának modellálása.

A képinterpretáció folyamatát a multimodalitással foglalkozó kutatók és többnyire a kognitív nyelvészek is kommunikációs folyamatként értelmezik. A mütárgy kommunikál a befogadóval, az üzenet pedig egy

jelenségeknek főként kulturális ismereteink alapján jelentést tulajdonítunk. Így a kalapemelés aktusát az európai kultúrkörhöz való tartozásunk és a középkori lovagkori szokások miatt üdvözlésként értelmezzük. A harmadik az ikonológiai szint, amelyben a lényegi értelem az adott korszak világnézetének ismerete révén válik megragadhatóvá. Az üdvözlésen túl a kalapját emelő személy társadalmi státuszára, hangulatára, nemzetiségére is következtethetünk. A gimnáziumi művészettörténeti oktatás Panofsky módszertanán alapul (Beke, 2004). 
A kortárs képelemzés kognitív szempontú megközelítése

fogalmi metafora vagy fogalmi metonímia formájában jelenik meg (Forceville; Šorm és Steen; Isaeva és Michlanova). A kognitív tudományokkal foglalkozó kutatók és kognitív pszichológusok a képinterpretációt problémamegoldó folyamatként értelmezik, amiben fontos az újrastrukturálás, a reflexió és a konstrukció folyamata (Saariluoma; Kuuva). A művészeti osztályokban végzett képinterpretációs vizsgálataim is ez utóbbit támasztották alá, ezért a kidolgozott módszertannak kardinális pontja, hogy magyarázatot ad arra, miért lehet több jelentése egy dolognak ${ }^{3}$.

A következőkben azokat az elemzési módszereket illusztrálom példával, amelyek befolyásolták az új módszertan kialakítását. Kuuva kognitív pszichológiai befogadás-modellje $^{4}$ strukturálja a kognitív nyelvészeti Forceville, valamint Isaeva és Mischlanova - metaforaazonosító eljárásait és a szimbólumok jelentésének vizsgálatát.

\footnotetext{
${ }^{3} 2016$ szeptemberétől empirikus vizsgálatokat végzek művészeti középiskolák végzős hallgatóival. A vizsgálat nem reprezentatív, eddig tizenkét beszélgetésre került sor. Ebben a dolgozatban azokra a megfigyelésekre utalok, amelyek a résztvevők több mint felénél egyezést mutattak. A vizsgálat során a diákok ugyanazt a képsort nézik végig számítógépes kijelzőn (a képeken házak láthatóak képzőművészeti alkotásokon). Kérdéseim: Képzeld azt, hogy én semmit sem látok, mond el, hogy Te mit látsz? Mit jelent számodra ez a képzőművészeti alkotás, hogyan értelmezed? Majd megmondom az alkotás címét (ez a kijelzőn is megjelenik: alkotó, cím, évszám) és újra rákérdezek: hogyan értelmezed az alkotást? A diákok nyitottak a kortárs műalkotások felé, nem érzik úgy, hogy egy megtanult anyagot kellene visszamondaniuk, ezért minden művészettörténeti, és hétköznapi élettapasztalatukat, élményüket latba vetve próbálják meg értelmezni a tárgyat. A vizsgálat egy órája után eddig minden résztvevő maradt még legalább egy fél órát, mert további kérdései voltak, vagy szerette volna megosztani egyszerűen az élményeit.

${ }^{4}$ Ester Šorm és Gerard Steen célja az volt, hogy a vizuális metafora érzékelésének és értelmezésének bemutatására elméleti modellt hozzanak létre (Šorm és Steen, 2013). Empirikus kísérletben különböző vizuális műfajból mutattak képeket holland könyvtárlátogatóknak. A résztvevők feladata az volt, hogy „hangosan gondolkodva” meséljenek a képekről. Šorm és Steen modelljét elvetettem, mert az a forrás- és a céltartomány közötti összeférhetetlenséget a vizuális metaforák alapprincípiumának tekintette, ezzel pedig Forceville (2002) és Thomas van Rompay (2005) nyomán nem értek egyet.
}

\section{Képelemzések a kognitív nyelvészetben}

Lakoff és Johnson gyakran idézett kijelentése, hogy „a metafora egy mindent átható hétköznapi jelenség, nemcsak a nyelvben, hanem a gondolkodásban és a cselekvésben is jelen van. Hétköznapi fogalmi rendszerünk, amelynek segítségével gondolkodunk és cselekszünk, alapvetően metaforikus természetü." (Lakoff és Johnson, 1980. 3.o.) A kognitív nyelvészet elsőleges vizsgálati tárgya a nyelv, így a legtöbb módszertan a verbális metaforák elemzésére és azonosítására vállalkozik (Pragglejaz Csoport, MIP, 2007; Steen, MIPVU (Five step method) 2010, 1999, 2009, 2011)5.

Forceville reklámokat, műfajfilmeket, animációt és képregényeket vizsgált, amelyeken keresztül tipizálta a vizuális módban megjelenő metaforákat (l. A metafora) és jellemezte a müfajokat. Intuitív módszertana a következő kérdéssorra támaszkodik: „1. Mi a két tartomány és ezt honnan tudjuk? 2. Melyik a cél- és melyik a forrástartomány? Ezt honnan tudjuk? 3. Melyek a megfeleltethető tulajdonságok és hogyan dől el a szelekció?" (Forceville, 2009, 2010). A nyelvész egy cipőreklám (2. ábra) elemzésekor leírja, hogy a képen egy öltönyös férfitestet látunk, a nyakkendő helyén azonban egy férficipő van. A két tartomány a CIPŐ és a FÉRFI ÖLTÖZÉK vizuálisan jelenik meg. A CIPŐ a céltartomány, amely a középpontban van, hiszen ez a reklámozott termék.

\footnotetext{
${ }^{5}$ A kognitív nyelvészeket sokáig az a kritika érte, hogy elemzéseik, metaforaazonosítási eljárásaik intuíción alapulnak. A kritika nem volt alaptalan, hiszen objektív módszertant Lakoff és Johnson, Kövecses, Forceville sem használtak. A későbbi metaforaazonosítási módszerek (MIP - Metaphor Identification Procedure, MIPVU - a MIP továbbfejlesztett változata, amely a Vrije Universiteit Amsterdam kutatócsoportjához köthető, Steen 2007) a verbális anyagot először holisztikus módon kontextusban vizsgálták. Majd az egységekre (legtöbbször szavakra, kifejezésekre) osztott szöveget szótárak segítségével meghatározták. A kutatók a módszerek segítségével a kontextusban használt és az általános jelentést (a szemantika ebben nagy szerepet játszott) hasonlították össze és amennyiben az összehasonlítás jelentősnek bizonyult metaforikusként azonosították. Míg a MIP a metaforikus értelemben használt nyelvi kifejezésekre, addig a MIPVU a metaforához kapcsolódó nyelvi kifejezéseket is vizsgálja, ezért a vizsgálat érzékenyebb és a jelentések mélyebb rétege tárható fel.
} 
Virág Ágnes

A NYAKKENDŐ a forrástartomány, amelyet a ális metafora. A megfeleltetett tulajdonság a férfiöltönyből és a cipő pozíciójából, vagyis a kontextus alapján találhat ki a szemlélő. A CIPŐ NYAKKENDŐ monomodális kontextu„nem funkcionális szépség”, ami a reklám műfajára jellemző pozitív tulajdonságként kapcsolódik a termékhez (Forceville, 1996).
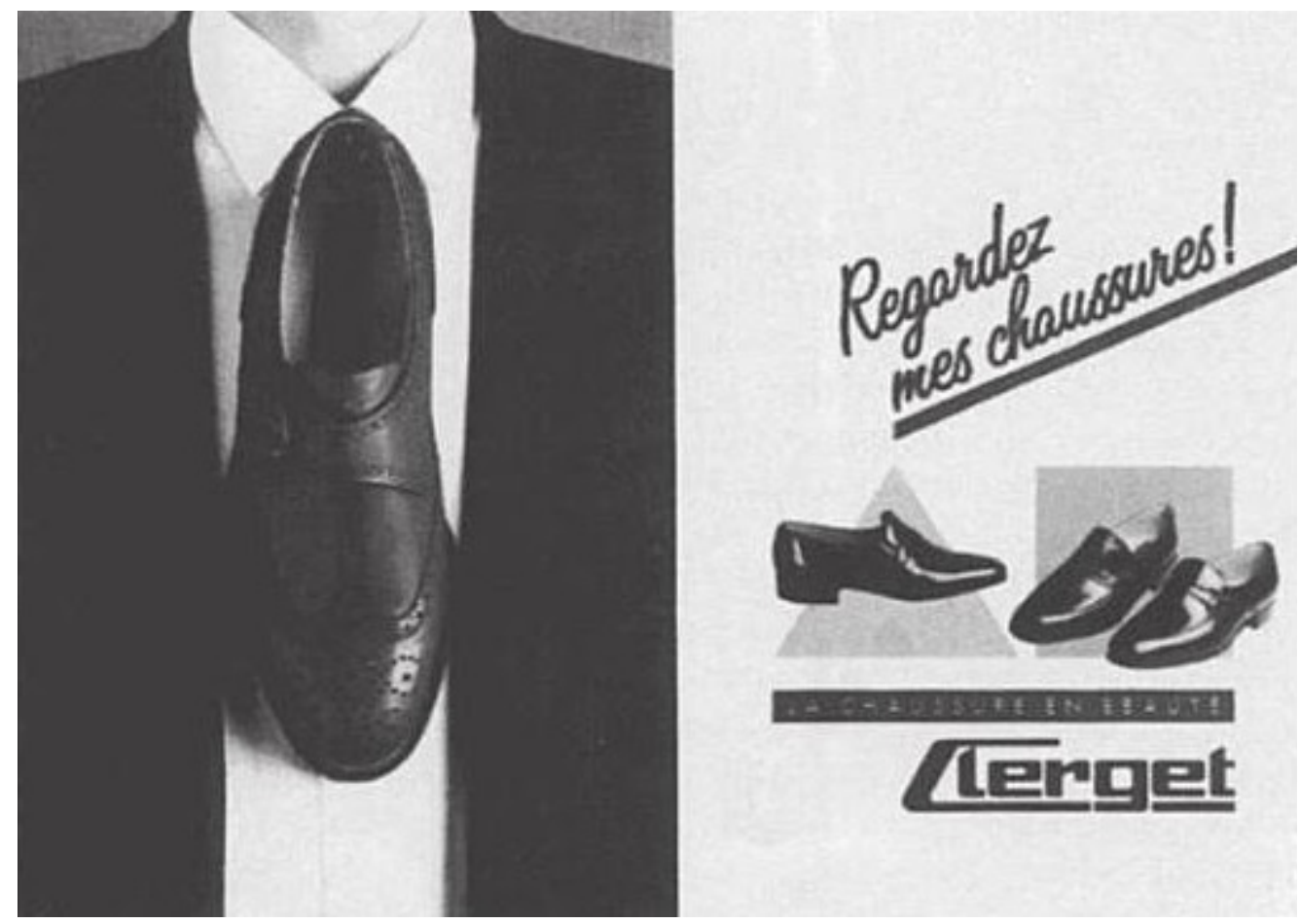

2. ábra: A CIPŐ NYAKKENDŐ kontextuális metafora (Forceville, 1996)

Ekaterina Isaeva és Svetlana Mishlanova nyelvészek Steen módszerét, az ún. MIPVU-t módosították (2015). Az intuitív módszertan helyett szisztematikus elemzési lépéseket követve arra voltak kíváncsiak, hogy a vizuális metaforák milyen tudást közvetítenek. Egy második világháborús propaganda plakátot, Kukryniksi „Minden kalendárium hazudik”, 1942 címü munkáját elemezték (3. ábra). A képen egy Hitler-fejü antik szobor testü figura szájából kalendáriumlapok szállnak a levegöbe. A lapokon különböző jelszavak - „Győzni fogunk!”, „A háborúnak vége!” - olvashatók. Az alakot pulpitus választja el a Goebbels-fejü varangytestủ lénytől. Forceville szerint a propagandaplakátok didaktikusak és direktek, így más képzőművészeti müfajoknál gyakrabban tartalmaznak piktorális metaforát (Forceville, 2013, l. A metafora), ezért nem tartom szerencsésnek az orosz kutatók választását, hiszen a mủfaj jellege miatt módszerük nem feltétlenül alkalmazható más művészeti müfajok esetén. A vizuális alkotásokban megjelenő metaforák céltartománya körvonalazható, de nem mindig konkrétan megnevezhető, míg a politikai karikatúra olyan műfaj, amelyről feltételezhető, hogy ironikus vagy negatív módon utal politikusra, vagy politikai szituációra.

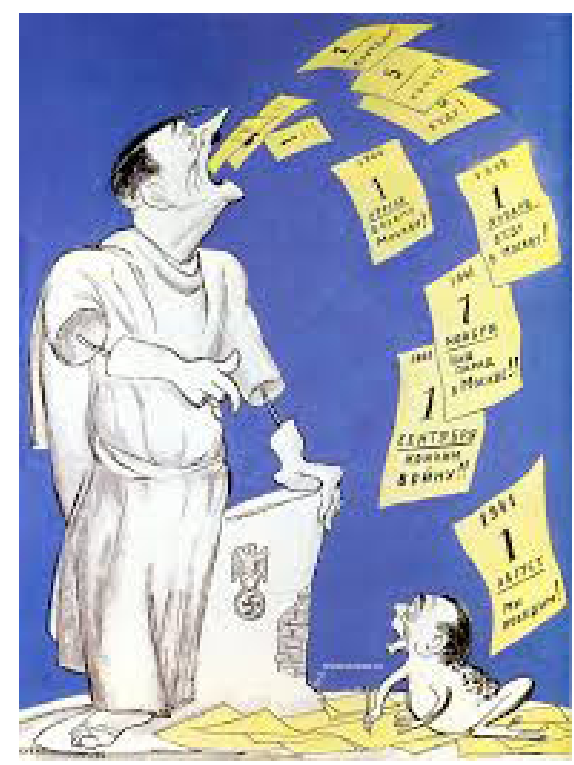

3. ábra: Kukryniksi:

„Minden kalendárium hazudik”, 1942. 
A kortárs képelemzés kognitív szempontú megközelítése

Isaeva és Michlanova szimbólumtárak segítségével megvizsgálták a vizuális elemek (például kirepül, szobor) általános jelentését, amit összevetettek a kontextuális jelentésekkel. Ha a két jelentés a köztük lévő ellentmon- dás ellenére összehasonlítható volt, akkor a vizuális elemet metaforikusként jelölték. Az egymáshoz kapcsolódó fogalmakat összekapcsolták és jelezték, hogy azok a cél-, vagy a forrástartományhoz tartoznak. Például:

$$
\begin{array}{lll}
(\text { KIFEJEZÉS } & \text { KIEJT } & \text { FEJ })_{\text {cél }} \\
(\text { LAP } & \text { KIREPÜL } & \text { NYOMDAGÉP/NYOMTATÓ) } \\
\text { forrás }
\end{array}
$$

Ez alapján láthatóak lettek a forrás- és a céltartományok közötti megfeleltetések, amelyben a nyomdagépből kirepülő lap azonosítható a Hitler-fej által kiejtett kifejezésekkel. Elemzésük eredményét így összegezték: a Hitler-fejű római szobor és a pulpitus a Führer nyilvános beszéd iránti rajongását fejezi ki, ugyanakkor szimbolizálja Hitler nemzeteket elnyomó személyét. Hitler nyomdagéphez hasonló gépies személyisége már eltávolodott a realitástól és megállás nélkül ontja magából az ígéreteket, amit a kalendárium időjárás előrejelzései is megerősítenek. A szobor töredékessége ironikus utalásként Hitler nagyszabású terveit teszi nevetségessé. A Hitler SzOBOR vizuális metaforához kapcsolódik a Goebbels varangy vizuális metafora. Hitler szobor szájából kirepülő PAPÍROK ÉS Goebbels alaKJa A NÁCI SAJTÓ ÉS A PROPAGANDA HELYETT ÁlL (metonímia).

A kutatók az elemzés során a színekre, a méretekre, a kompozicionális elemekre, a gesztusokra nem fordítottak figyelmet. Kétségesnek tartom a formalista jellegü, szinte képletszerű módszer alkalmazhatóságát a vizuális metaforaelemzésekben. A modell egyik lényeges lépése viszont arra hívja fel a figyelmet, hogy szimbólumok esetén érdemes összevetni a kontextuális és az általános jelentést szimbólumtárak és képi analógiák segítségével. Ezt Panofsky (1955/84) és Kuuva (2007) is alkalmazza.

\section{Képelemzések a kognitív pszichológiában}

Sari Kuuva (2007) kidolgozta annak modelljét, hogyan tapasztaljuk meg a vizuális alkotásokat és hogyan hozunk létre mentális repre- zentációkat (Kuuva, 2007, 2010). Empirikus kísérleteiben kulcsfontosságú volt az érzékelhető és az elvont tartalmak megkülönböztetése.

Kuuva a képmagyarázat folyamatát problémamegoldó aktusnak tartja és a diagnoszták, vagy a sakkjátékosok gondolkodásához hasonlítja. Érzékeljük (percepció) és értelmezzük a vizuális alkotást. Az érzékelést a figyelem irányítja. Az értelmezés része az appercepció (tudatosítás), az újrastrukturálás, a reflexió és a konstrukció. A kísérletek bizonyították, hogy a szemlélők vizuális percepcióikat nem érzékelhető fogalmak segítségével próbálják jelentéssel bíró mentális reprezentációvá rendezni, ezt nevezzük appercepciónak. Példájában egy művészettörténész hallgató Pasi Tammi $A$ vers térdre kényszerit (1999) címü festményét elemzi (4. ábra). Először megfigyeli a világos és sötét részeket és az emberi figura pozícióját, vagyis érzékelhető tartalmakkal jellemzi az alkotást. A tudatosítás során a tanuló meglátja a szárnyakat, majd arra következtet, hogy egy angyalról lehet szó. Az angyal nem érzékelhető tartalom, nem jelenik meg a képen. A szemlélő úgy gondolja, hogy egy bukott angyalt lát, aki rosszat tett és ezért elveszítette a szárnyait. A rosszcselekedet és a pozícióvesztés nem látható a képen. A tanuló produktív módon elképzeli az angyalt, mert értelmezni szeretné a látottakat. A sötétség (érzékelhető) miatt a kárhozatra asszociál (nem érzékelhető), talán éppen azért, mert a férfit bukott angyalként látta. Az újrastrukturálás az egyik mentális reprezentációról egy másikra való áttérés. Ugyanabban az időben nem tudunk több egymásnak ellentmondó mentális reprezentációt megragadni, ezért váltásra van szükség. A hallgató újra megné- 
zi a képet, a színek kontrasztját, majd a szárnyakat is, amit a cukorangyalkák szárnyához hasonlít. Észreveszi, hogy a szárnyak egy hatytyúhoz tartoznak, amit a férfi ölel át. Elkezdi újrastrukturálni a korábbi interpretációt, hiszen az angyal fogalma ellentmond a hattyúnak. Látja, hogy a fehér szárnyak koszosak, úgy tűnik, hogy az állat elpusztult. Talán olajfolt. Az alkotásnak a környezetre vonatkozó üzenete lehet. Az újrastrukturálás összefügg az érzékeléssel és új mentális reprezentációhoz vezet. Az új interpretáció azonban nem törli el teljes egészében a korábbi megfigyeléseket. A különböző mentális reprezentációkat a reflexió során összehasonlítjuk és választunk az alternatívák közül. A konstrukció annyit jelent, hogy az al-reprezentációkat koherens egésszé integráljuk. A tanuló még mindig használja a kárhozat és a szomorúság kifejezéseket, de azokat a természet elpusztításával kapcsolja össze. Látható, hogy a képelemzés folyamata nem lineáris, hanem inkább olyan, mint egy ciklus, aminek minden része az appercepcióhoz kapcsolódik. Az interpretáció folyamata addig folytatódik, ameddig elfogadható megoldás nem születik a kép értelmére vonatkozóan. A példa jól illusztrálja a képinterpretációban müködő konstruktív, kreatív gondolkodást.

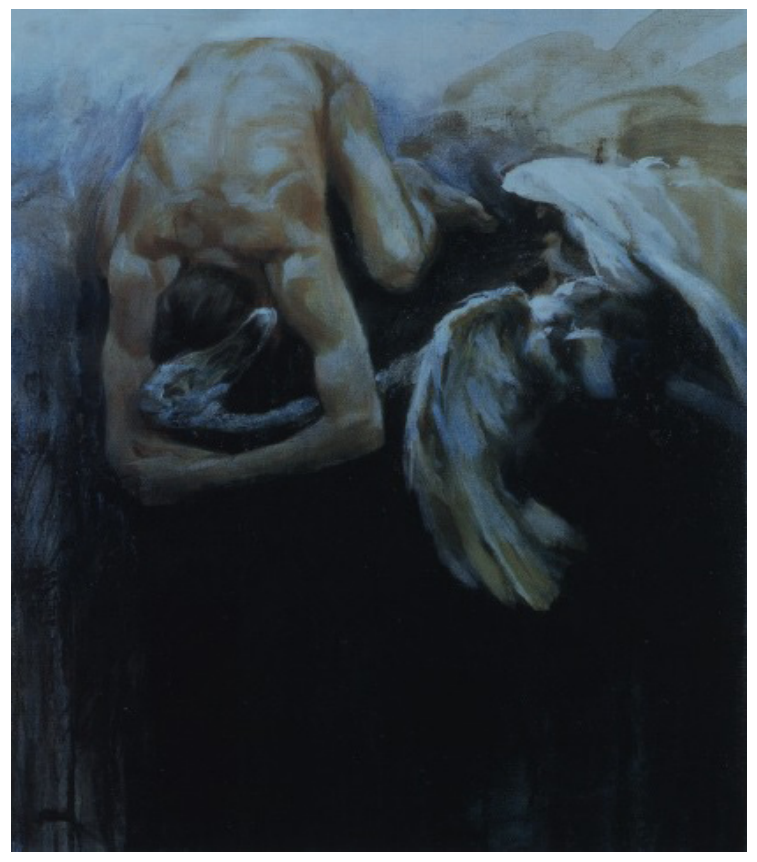

4. ábra: Pasi Tammi: A vers térdre kényszerít, 1999.
Az elemzés szemléletesen mutatja, hogy az interpretáció nem lineáris, a vizuálistól a fogalmi gondolkodásig vezető folyamat. Kuuva módszerének előnye, hogy számos részletre kiterjed, ami szisztematikussá és mérhetővé teszi a vizsgálatokat. Magyarázatot ad arra, hogyan lehetséges az, hogy egy-egy alkotásnak többféle jelentése lehet. Modellje a müvészettörténeti dokumentumok megvitatásának is eszköze lehet.

\section{Kognitív szempontú módszertan vizuális elemzésekhez}

A képzőművészeti tárgyak befogadásának vizsgálata azért is bonyolult, mert a folyamat legtöbbször verbális magyarázatok nélkül, csendben egy katalógust lapozgatva, vagy egy kiállítótérben történik. Ami leginkább megragadható, az maga a műalkotás, a művészek feljegyzései, naplói, blog bejegyzései, valamint a szakemberek eltérő műfajokban született írásai és szóbeli közlései. Az elemzési módszer kidolgozása során arra törekedtem, hogy a folyamat minél inkább tükrözze a természetes befogadás folyamatosan újraértelmező fázisait, azt, ahogyan a gondolatainkat újrastrukturálhatjuk ugyanazon tárgy szemlélése közben. Hiszen amint láttuk, könnyen megtörténhet, hogy egy mütárgyon első látásra egy szárnyait vesztett bukott angyalt látunk, majd ha jobban megnézzük azt, akkor inkább úgy véljük, hogy az esendő és pusztító emberiséget szimbolizáló férfialak átöleli az olajfoltos szárnyú hattyút (Kuuva, 2007).

A módszer három föbb részből áll (1. táblázat) - az első rész az érzékelhető tartalmak leírása, az érzékeléskor létrejövő metafora azonosítása és az aktivált keretek meghatározása. A második lépésben az alapjelentések és a keretek kifejtésének segítségével határozzuk meg a kognitív folyamatokat. Végül a harmadik lépésben új kontextus bevonásával kulturálisan specifikus vagy egyedi jelentések vizsgálhatók. Úgy vélem, hogy a kognitív szempontú tartalomelemzés rajzórai, múzeumpedagógiai foglalkozás, de akár tárlatvezetésnek is fontos része lehet. Ebben a feltevésemben László 
A kortárs képelemzés kognitív szempontú megközelítése

Zsófia a Szépművészeti Múzeum múzeumpedagógusa is megerősített, amikor a módszert és az elemzést olvasva ezt írta: „A múzeumban dolgozó pedagógusoknak alapvetö dolog a munkájukhoz, hogy olyan mindenki számára érthetö és hozzáférhetö alapokat találjanak a foglalkozások során a müvészetröl való beszédhez, amin el lehet indulni. Szerintem a legtöb- ben, akik jók ebben a dologban hasonló módon közelitettek a kortárs müvészethez, dolgoztak ki tematikus foglalkozásokat. Ez a dolog szerintem elsősorban abban segit, hogy tudatosithatja ezt a többnyire csak ösztönösen alkalmazott módszert. Tudományos alapokat ad, és akár tanithatóvá is teszi, múzeumpedagógus hallgatók számára." (2016. október 4.)

\begin{tabular}{|l|l|}
\hline 1. lépés: Érzékelés & $\begin{array}{l}\text { 1.1 Érzékelhető fogalmak leírása (Kuuva, 2007) } \\
\text { 1.2 Az érzékelhető metafora meghatározása (Forceville, 1996-2009) } \\
\text { 1.3 Az aktivált keretek azonosítása }\end{array}$ \\
\hline $\begin{array}{l}\text { 2. lépés: Értelmezés } \\
\begin{array}{l}\text { Hétköznapi tudás alapján } \\
\text { metonímiák azonosítása }\end{array}\end{array}$ & $\begin{array}{l}\text { a) A kortárs alapjelentések azonosítása (Isaeva és Mishlanova, 2015; Kuuva, 2007) } \\
\text { b) A fogatek kifejtése (Kövecses és Benczes, 2010; Lakoff és Johnson, 1980) } \\
\text { (Forceville, 1996-2009; Isaeva és Mishlanova, 2015) }\end{array}$ \\
\hline $\begin{array}{l}\text { 3. lépés: Új kontextus } \\
\text { bevonása } \\
\begin{array}{l}\text { Speciális tudás alapján } \\
\text { egyedi metaforák és } \\
\text { metonímiák azonosítása }\end{array}\end{array}$ & $\begin{array}{l}\text { 3.1 A mútárgymagyarázat kognitív nyelvészeti elemzése a kognitív } \\
\text { pszichológiából ismert folyamat tükrében. (Kövecses és Benczes, 2010; Kuuva, } \\
\text { 2007, 2010) } \\
\text { 3.2 A fogalmi metaforák és metonímiák azonosítása (Kövecses és Benczes, } \\
\text { 2010; Forceville,1996-2009) }\end{array}$ \\
\hline
\end{tabular}

1. táblázat: Az új módszertan három lépése

Nézzük meg egy példán keresztül, hogy mi történik az első lépésben, amikor a hétköznapi észlelés és érzékelés alapján vizsgáljuk a tárgyat (2. táblázat). Azokat a jellemzőket vesszük figyelembe, amiket a legtöbb szemlélő valószínűleg lát és megfigyel. Ez a tárgyleírás nagyrészt megegyezik a vizuális nevelésben jelenleg is alkalmazott módszerekkel és segít tudatosítani, rendszerezni azokat a tartalmakat, amiket szinte egyszerre fogunk fel (bár az idegtudományi vizsgálatok bizonyították, hogy először a színt, majd a formát és végül a mozgást érzékeljük, Kuuva, 2007). Az elemzés a leírást követően az érzékelhető metafora és az aktivizált keretek meghatározásával foglalkozik. Az érzékelhető metafora annyit jelent, hogy a metaforának a forrás- és céltartománya is megjelenik vizuálisan, vagy verbálisan (a mütárgy részeként, vagy a címben).

Először a tárgyra vonatkozó vizuálisan érzékelhetö fogalmakat vesszük sorra: az alakokat és a tárgyakat, a formákat és a felületre vonatkozó tulajdonságokat, a színeket és az értékeket, a térre és az időre, az akcióra és a figuramozgásra vonatkozó kifejezéseket gyüjtünk (Kuuva, 2007). Baglyas Erika instal- lációját (1. ábra) szemlélve a megfigyeléseket három csoportba osztjuk: az elsőbe tartoznak a vizuális módban megjelenő fogalmak: ház, persely, 3D-s üreges tárgy lyukakkal, feketefehér, átlátszó üveg alap, pénz bedobása a dobozba. A befogadó már az érzékelésnek ebben a fázisában automatikusan létrehozza a PERSELY HÁz vizuális monomodális metaforát (Forceville terminológiájával hibridet), amely két alapvető fogalmi metafora kombinációjára vezethető vissza. Ezek A HÁz TARTÁLY és A PERSELY TARTÁly fogalmi metaforák. Ez a monomodális piktorális metafora megalkotható a figurák és a tárgyak, valamint az akciók és a figuramozgások figyelembevételével: mindkét tartománya vizuális módban jelenik meg. A ház és a persely, amelyek tartályszerü struktúrájuk révén kapcsolódnak egymáshoz, megosztják a „magában foglalás” keretet. Az empirikus felmérések során nem volt olyan középiskolás, aki ne úgy beszélt volna a házról, mint egy dobozszerü tárgyról, ami magában foglalja az apró pénzérméket. A forrástartomány a konkrétabb, leginkább szembeötlő HÁz, míg a céltartomány a PERSELY, ami aktiválja az „adományozás” keretet. Ezt a mütárgyon szereplő feliratok, a pénzérmék, a 
kéményen lévő lyuk és az átlátszó házalap, tehát vizuális és verbális tartalmak is megerősítik. A persely olyan, mint egy ház, amelyben a persely és a ház forma is elvontabb dolog helyett áll (ezeket a metonimikus viszonyokat az elemzés második lépésében tárgyalom, mivel az appercepcióhoz tartoznak és megjelenik bennük olyan elem, ami nem érzékelhető).

Az érzékelés második és a harmadik csoportjába tartoznak a verbálisan érzékelhetö fogalmak: egy műtárgyon megjelenő szó és/vagy az alkotás címe. A két verbálisan érzékelhető tartalmat azért különítettem el egymástól, mert az alkotás részeként megjelenő verbális elem szorosabban kapcsolódik a mütárgyhoz, koherens része annak, nem úgy, mint a cím. A mütárgy címét is az érzékelhető tartalmak között tárgyalom, hiszen feliratként gyakran szerepel közvetlenül a mütárgy mellett. A Baglyas installáció címe - „Jó előre gondoljon a jövőjére!” - aktiválja a „megtakarítás” keretet. Amikor a diákok megtudták a mütárgy címét, azonnal a Jövő és az ÉLET céltartományokkal kezdtek el foglalkozni és minden addigi megfigyelésüket ezekre vonatkoztatták, vagy ennek szellemében kezdték átstrukturálni korábbi mentális reprezentációikat.

Az elemzés első fázisának eredményeképpen megragadható A PERSELY HÁz fogalmi metafora, amely a "magában foglal” kereten alapul, valamint két további keretet - az „adományozást” és a „megtakarítást” - aktiváljuk. Az érzékelhető tartalmak leírásakor Kuuva (2007) vizuális fogalmak vizsgálatára kifejlesztett szempontrendszerét alkalmaztam. A vizuális és a verbális módokat Forcevillehez hasonlóan megkülönböztettem, ennek köszönhetően átláthatóvá vált az a folyamat, ahogyan a vizuális és a verbális módok összekapcsolódnak a vizsgált tárgy érzékelésekor.

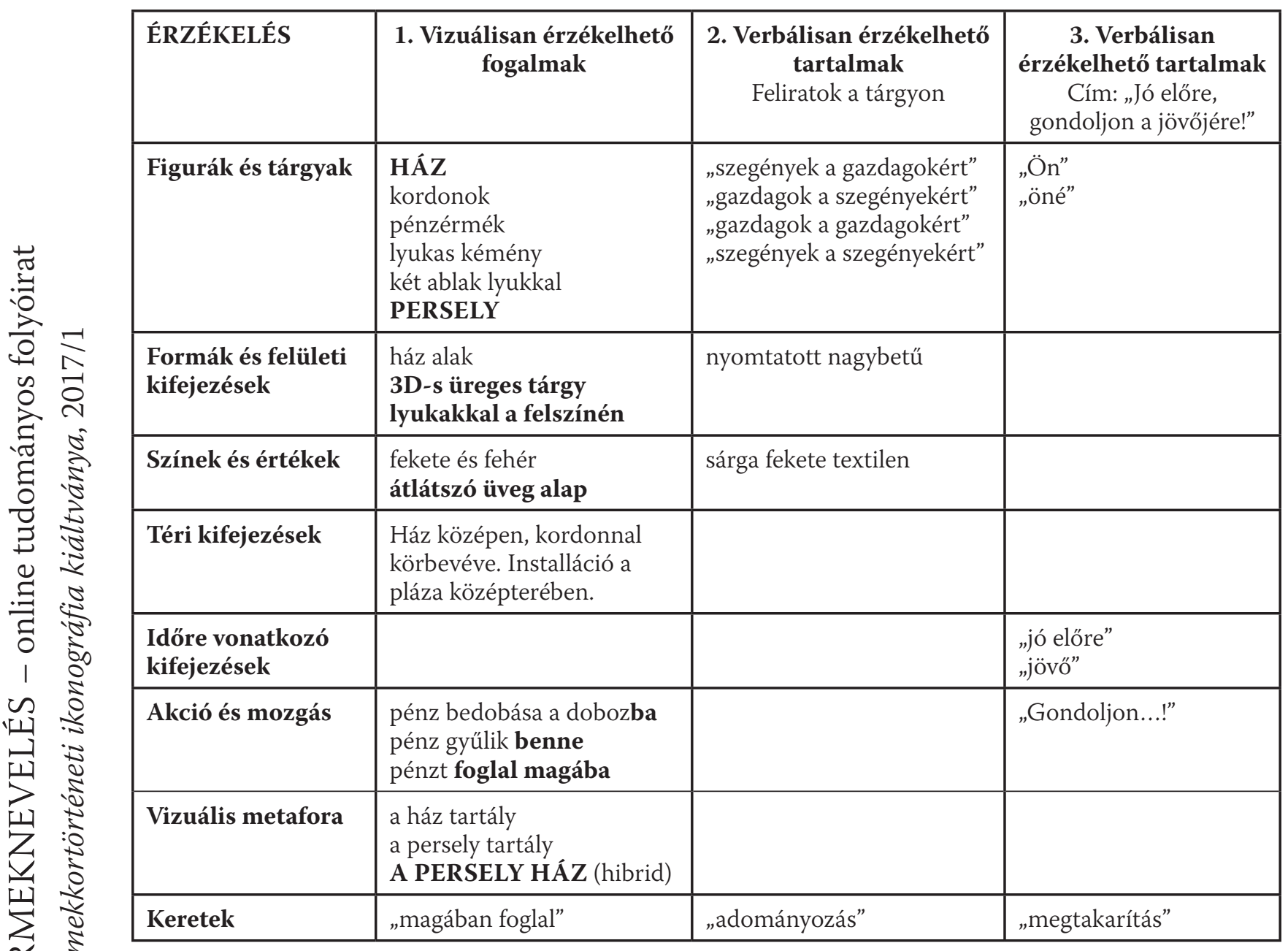

2. táblázat: Az érzékelhető fogalmak leírása 
A kortárs képelemzés kognitív szempontú megközelítése

Az elemzés második lépése az appercepcióval foglalkozik, amelyben a közvetlenül nem érzékelhető fogalmakat tárgyalom. Először a szimbólumok alapjelentéseit veszem sorra (3. táblázat), ezután kifejtem az aktivizált keretek elemeit (4-6. táblázatok). Az alapjelentések és a keretelemek segítségével meghatározhatók a metaforikus és a metonimikus folyamatok. A szimbólumtárak, jelképtárak, szociológiai tanulmányok kritikai használata megszokott a művészettörténeti elemzésekben (Panofsky, 1984; Kuuva, 2010). Az újdonság a kognitív nyelvészeti módszer alkalmazása, azaz a keretek kifejtése, a metaforák és a metonímiák azonosítása (Lakoff és Johnson, 1980; Forceville, 1996, 2009; Isaeva és Mishlanova, 2013).

Az érzékelhető tartalmak közül kiválasztjuk azokat, amikhez elvont jelentés társulhat az adott műtárgy-kontextusban. Baglyas Erika installációja esetén ezek a ház, a pénz és a fekete-fehér fogalmak (3. táblázat). Az általános szimbolikus jelentésre vonatkozóan a házról a szimbólumtár (Pál és Újvári, 1997) alapján elmondható, hogy jelképezheti a lakóhelyet, a menedéket, a társadalom és a család alapját, az emberi élet középpontját, valamint a családi biztonságot. A szociológiai felmérés (Kapitány és Kapitány, 2005) arra világít rá, hogy a magyarok a házat a felnőttkorhoz, a biztonsághoz, a legfontosabb dolgokhoz, a vágyott tárgyakhoz és az ideális élethez szükséges dologként tartják számon. Ugyanígy megvizsgáljuk a pénz és a fekete-fehér fogalmakat. A lenti táblázatban csak azokat a jelentéseket tüntettem fel, amelyek relevánsak lehetnek a műalkotásra vonatkozóan.

\begin{tabular}{|c|c|c|}
\hline $\begin{array}{l}\text { Szimbolikus } \\
\text { jelentések }\end{array}$ & $\begin{array}{l}\text { Alapjelentések a szimbólumszótár } \\
\text { alapján } \\
\text { (Pálés Újvári, 1997) }\end{array}$ & $\begin{array}{l}\text { Alapjelentések a magyarok körében } \\
\text { végzett szociológiai felmérés alapján } \\
\text { (Kapitány és Kapitány, 2005) }\end{array}$ \\
\hline Ház & $\begin{array}{l}\text { 1. lakóhely, menedék, körbevett, védett } \\
\text { hely } \\
\text { 2. a társadalom és a család alapja } \\
\text { 3. az élet központja } \\
\text { 4. családi biztonság }\end{array}$ & $\begin{array}{l}\text { 1. felnőttkor } \\
\text { 2. az identitás kifejezése } \\
\text { 3. biztonság } \\
\text { 4. a legfontosabb örökölt tárgy } \\
\text { 5. vágyott tárgy } \\
\text { 6. a legfontosabb tárgy a barátok között } \\
\text { 7. szükséges az ideális élethez }\end{array}$ \\
\hline Pénz & $\begin{array}{l}\text { 1. anyagi érték, haszonszerző } \\
\text { gondolkodásmód } \\
\text { 2. világi javak }\end{array}$ & $\begin{array}{l}\text { 1. gyerekkor } \\
\text { 2. értékes tárgy } \\
\text { 3. felnöttkor } \\
\text { 4. modernitás, trendiség } \\
\text { 5. vágyott tárgy }\end{array}$ \\
\hline Fekete és fehér & & $\begin{array}{l}\text { 1. minimál stílus a modernitás helyett } \\
\text { 2. üveg mint anyag a modernitás helyett } \\
\text { 3. fizikai egyszerüség a puritán értékek } \\
\text { szerint }\end{array}$ \\
\hline
\end{tabular}

3. táblázat: A vizuálisan érzékelhető fogalmak szimbolikus alapjelentése

Az alapjelentések vizsgálata után az aktivizált keretek kifejtése következik. A keretelemeket konkrét tartalmakkal töltöm ki. Ha a különböző tartományok keretelemei között legalább egy megfelelés van, akkor a két tartomány közötti viszony metaforikus (Forcveille, 2002). Az első a „magában foglalás” kerete (4. táblázat), amelynek része a külső tér, a belső tér, a ki- és bemeneti nyílás(ok) és a tartalom. A táblázatból látható, hogy megfeleltetések jönnek létre a TARTÁLY, a HÁz és a PERSELY között. A ház funkciója tehát az lesz, hogy magában foglalja a pénzérméket (kontextustól függetlenül a ház- nak számos más funkciója is lehetne, például az a hely, ahol biztonságban vagyunk). A képzőművészeti alkotásokban szereplő házak falai gyakran „sérültek”. A sérülés nem természeti kár, vagy a múló idő következménye, hanem szándékos művészi határsértés, amelyen keresztül a ház be-, illetve átláthatóvá válik. Ebben az esetben ilyen határsértés az átlátszó házalap, amely a házat lebegő tárgyként mutatja, másrészt láthatóvá teszi a belsejében gyűlő pénzérméket. Ha ez nem így lenne, akkor a „magában foglalás" keret és A PERSELY HÁz fogalmi metafora nehezen, vagy nem jöhetne létre. 


\begin{tabular}{|l|l|l|}
\hline \multicolumn{3}{|c|}{ „Magában foglalás” keret } \\
\hline \multicolumn{1}{|c|}{ PERSELY (céltartomány) } & \multicolumn{1}{|c|}{ HÁZ (forrás) } & \multicolumn{1}{|c|}{ TARTÁLY (forrás) } \\
\hline Külső tér & Külső tér & Külső tér \\
Belső tér & Belső tér & Belső tér \\
A persely fala & Fal & A tartály fala \\
Lyuk & Nyílászárók, lyukak (kémény) & Ki-és bemeneti nyílás \\
Pénz & & Bennfoglalt tartalom \\
\hline \multicolumn{2}{|l}{} \\
\hline \multicolumn{2}{|l|}{} \\
\hline
\end{tabular}

4. táblázat: A „magában foglalás” keret kibontása

A második keret az „adományozás”, amelyben a keretelemek: ki, kinek, mit, milyen célból, milyen módon, milyen eszközzel ad (5. táblázat). Az „adományozás” a pénzadás konkrét folyamatában jelenik meg és aktiválja a „segítségnyújtás” keretet, ami valójában nem érzékelhető. Ezt a kordonon szereplő „szegény és gazdag" fogalmak is megerősítik. A diákok a feliratok elolvasását követően a különböző társadalmi rétegek közötti feszültségekről és azok feloldásáról, például az adományozásról kezdtek el beszélni. A legtöbb esetben létrejött a SEGÍTSÉGNYÚJTÁS ADAKOZÁs fogalmi metafora. A 5. táblázatban látható, hogy az „adományozás” keret elemei kitölthetőek az érzékelhető tartalmak, vagyis a feliratok segítségével. Mivel a szemlélő kizárólag a kordon „szegények a gazdagokért” felirattal ellátott oldaláról tud pénzt a kéménybe dobni, ezért az adományozó a szegény, míg az adományt kapó a gazdag lesz. Érzékelhető az ellentét, amely bizonytalanságra ad okot, hiszen azt sugallja, hogy nem önkéntes adományozásról van szó. Az alapjelentésekből megállapítható, hogy a pénz, a mütárgy stílusa (fekete-fehér, minimál) és az anyaghasználat (üveg) a modern kor helyett áll, miközben a ház az ember számára fontos, vágyott és szükséges dolog helyett szerepel (Kapitány és Kapitány, 2005).

\begin{tabular}{|c|c|}
\hline \multicolumn{2}{|c|}{ Az „adományozás” és a „segítségnyújtás” keretek közötti megfeleltetések } \\
\hline Adományozó & Segítő - „Szegények” \\
\hline Adományozott & Segítségre szoruló - „Gazdagokért” \\
\hline Adomány & Segítség \\
\hline Az adományozás célja & „Mindenki feje fölött legyen fedél” \\
\hline Adományozás & Segítségnyújtás \\
\hline \multicolumn{2}{|c|}{$\begin{array}{l}\text { Eredmény: A MODERNKORI SEGÍTSÉGNYÚJTÁS (cél) ADOMÁNYOZÁS (forrás) } \\
\text { multimodális verbo-piktorális metafora } \\
\text { A PÉNZ, A STÍLUS ÉS AZ ÜVEG A MODERN KOR HELYETT ÁLL (metonímia) } \\
\text { A HÁZ FORMA A VÁGYOTT ÉS SZÜKSÉGES DOLOG HELYETT ÁLL (metonímia) }\end{array}$} \\
\hline
\end{tabular}

5. táblázat: Az „adományozás” keret kifejtése

Az utolsó, harmadik keret a „megtakarítás”, amelyet az elemzés első lépésében érzékelhető cím - „ó elöre gondoljon a jövőjére?" - aktivál (6. táblázat). Ennek elemei a pénzt megtakarító személy, a megtakarítás kedvezményezettje, az aktus ideje és célja. Az elemeket a cím segítségével töltöttem ki, ami feloldotta az „adományozás” keretben létrejövő szegény és gazdag közötti ellentétet, hiszen az új mentális reprezentáció (a „megtakarítás”) és a címben használt igei személyrag és birtokos személy- jel („Gondoljon...”, „jövőjére”) arra utal, hogy a megtakarító és a kedvezményezett ugyanaz a személy. Az „adományozás” keret helyett létrejön a „megtakarítás” keret. Ezt a folyamatot Kuuva újrastrukturálásként értelmezi a kognitív pszichológia keretében (2007, 2010). A műalkotás címe jelentősen hozzájárul ahhoz, hogy Baglyas Erika installációja kapcsán a szemlélő létrehozza Az ÉLETCÉL VAGYONSZERZÉs fogalmi metaforát, ami a fogyasztói társadalom gondolkodásmódját meghatározó 
A kortárs képelemzés kognitív szempontú megközelítése

fogalmi metafora. Ez a műalkotásban A BOLDOGABB ÉLET/A JOBB JÖVŐ A HÁZ MEGSZERZÉSE multimodális verbo-piktorális fogalmi metaforában testesül meg. A céltartomány a címben, míg a forrástartomány a vizuális módban a mütárgy formájában jelenik meg. A megkérdezett középiskolások mindegyike megjegyezte, hogy a cím ritmusa és csengése emlékezteti őket a reklámokból ismert banki szolgáltatások - lakáshitelek, lakáscélú megtakarítások - szlogenjeire, amik a jövőbeni boldogságot hirdetik.

A vizuális és a verbális elemek metonimikus úton erősítik a tárgy figyelmeztető jellegét. A pláza, ahol a műtárgyat installálták, feszültséget okoz, hiszen itt az ember nem szerez házat és nem takarít meg. Egyebek mellett szimbolizálhatja viszont a fogyasztói társadalmat. A „megtakarítás” keret és a fogyasztói társadalom összeférhetetlenségét $a$ cím imperatívusza és a kapitális sárga betük a kordonon hangsúlyozzák. A kordon védett dologra utal, itt a házat veszi körbe, ezért a tárgyra irányul a tekintet. Ezek a jellemzők a pláza ingergazdag környezetében is megragadják a vásárlók figyelmét.

A cím alapján a megtakarítás célja a jobb jövő, a boldogabb élet. A vizuális módban megjelenő ház forma miatt ez a cél a ház megszerzésére irányuló törekvésben körvonalazható. A HÁz MEGSZERZÉSE forrástartományon keresztül próbáljuk megfogalmazni azt, hogy mit jelent számunkra А јОвв јövő,
A BOLDOGABB ÉLET céltartomány. A megfeleltetett tulajdonság a "célorientált aktus", tehát a céltudatos élet kerül előtérbe. A forrástartomány keretelemei közül a pénzt és a házat a boldogsággal feleltethetjük meg. A BOLDOGABB ÉLET/A JOBB JÖVŐ A HÁZ MEGSZERZÉSE metafora metonimikus alapját a ház szimbolikus jelentése teremti meg, amelyben A HÁz A FELNŐTTKOR, A BIZTONSÁG ÉS A VÁGYOTT TÁRGY HELYETT ÁLl. Hasonló gondolatok fogalmazódnak meg az olyan verbális kifejezésekben, mint a „csak fedél legyen a fejünk felett”, vagy az „álmaink otthona”. Az ÉLETCÉl A HÁZ MEGSZERZÉSE fogalmi metafora a BOLDOGSÁG VALAMINEK A BIRTOKLÁsA elsődleges metaforán alapul. Ezt Joseph Grady az ATTRIBUTES ARE POSSESSIONS (A TULAJDONSÁGOK BIRTOKOLT TÁRGYAK) elsődleges metaforával fejezi ki (Grady, 1997. 109. o.). Például „Az új bajusz idősebb megjelenést biztosított számára." Ez alapján a fogalmi metafora AZ IDŐSEBB MEGJELENÉS BAJUSz. Az installációra vonatkoztatva pedig a BOLdogSÁg HÁz lenne. Lakoffnál ugyanez a gondolat a GETTING A PROPERTY IS GETTING A POSSESSION (EGY TULAJDONSÁG MEGSZERZÉSE EGY DOLOG MEGSZERZÉSE), a PURPOSES ARE DESIRED POSSESSIONS (A CÉLOK VÁGYOTT DOLGOK) éS a PROPERTIES ARE POSSESSIONS (A TULAJDONSÁGOK BIRTOKOLT TÁRGYAK) metaforákban jelenik meg (Lakoff, 1991. 6., 17. o.).

\begin{tabular}{|l|l|}
\hline \multicolumn{2}{|c|}{ "Megtakarítás” keret } \\
\hline Személy & „Ön” \\
\hline Személy részére & "Önnek” \\
\hline A megtakarítás ideje & "Oó előre” \\
\hline Az alany által meghatározott aktus & „Gondoljon...!” \\
\hline $\begin{array}{l}\text { A megtakarítás célja (verbális mód } \\
\text { alapján) }\end{array}$ & $\begin{array}{l}\text { BOLDOGABB JÖVÖ, JOBB ÉLET } \\
\text { (céltartomány) }\end{array}$ \\
\hline $\begin{array}{l}\text { A megtakarítás célja (vizuális mód } \\
\text { alapján) }\end{array}$ & A HÁZ MEGSZERZÉSE (forrástartomány) \\
\hline $\begin{array}{l}\text { Eredmény: A BOLDOGABB JÖVÖ/A JOBB ÉLET A HÁZ MEGSZERZÉSE } \\
\text { multimodális verbo-piktorális metafora }\end{array}$ \\
\hline
\end{tabular}

6. táblázat: A „megtakarítás” keret kifejtése 
Az elemzés első és második lépése alapján általános jelentésekre következtethetünk. Összefoglalóan az elemzés első részében az érzékelhető, a második részében a nem érzékelhető tartalmakat vizsgáltam. Az érzékelés során könnyen létrehozható A PERSELY HÁz monomodális metafora, amely A HÁz TARTÁLY és A PERSELY TARTÁLY metaforákon alapul. A szemlélődéskor aktivizálódott a „magában foglalás”, az „adományozás” és a "megtakarítás keret”. A második lépésben a szimbolikus jelentések vizsgálata és a keretek kifejtése révén meghatározhatók A SEGÍTSÉGNYÚJTÁS ADOMÁNYOZÁS éS A BOLDOGABB ÉLET/JOBB JÖVŐ A HÁZ MEGSZERZÉSE multimodális verbo-piktorális fogalmi metaforák. A középiskolásokkal készült empirikus vizsgálat megerősítette azt, hogy a diákok globális és lokális szinten is értelmezik a tárgyat. Globális szinten többen utaltak a plázákban, gyógyszertárakban, étkezdékben elhelyezett plexi adománygyüjtő dobozokra (5. ábra), valamint a minimál, modern stílusra (6. ábra), de amikor felfedezték, hogy a felirat „szegények a gazdagokért”, akkor perspektívát váltottak és újrastrukturálták az „adományozás” és a „segítségnyújtás” kereteket. Többen a jelenlegi adórendszerhez, a politikai visszaélésekhez és a társadalmi rétegek közötti szétnyíló ollóval hozták összefüggésbe a tárgyat, tehát lokális tapasztalataik alapján konstruáltak újabb mentális reprezentációt. Hárman megjegyezték azt is, hogy a „szegények a gazdagokért” a valóság, vagy az igazság és „tényleg mindig a szegények adják a legtöbb dolgot azért, hogy a gazdagok még gazdagabbak legyenek". A résztvevők ezzel utaltak a tárgy kritikai hangvételére is.

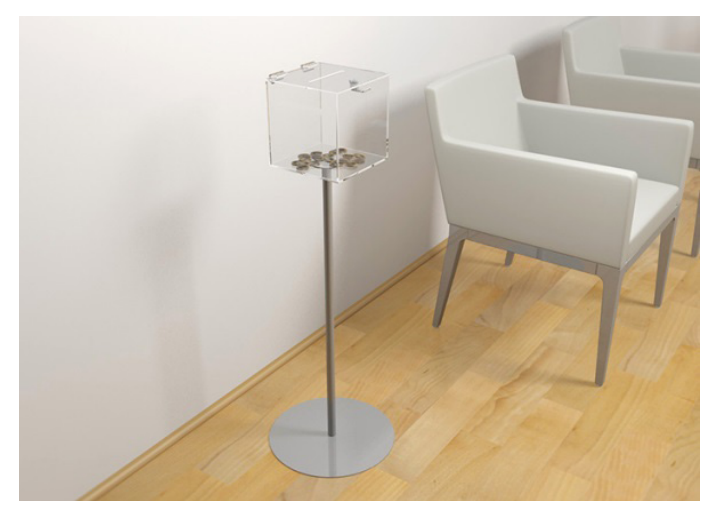

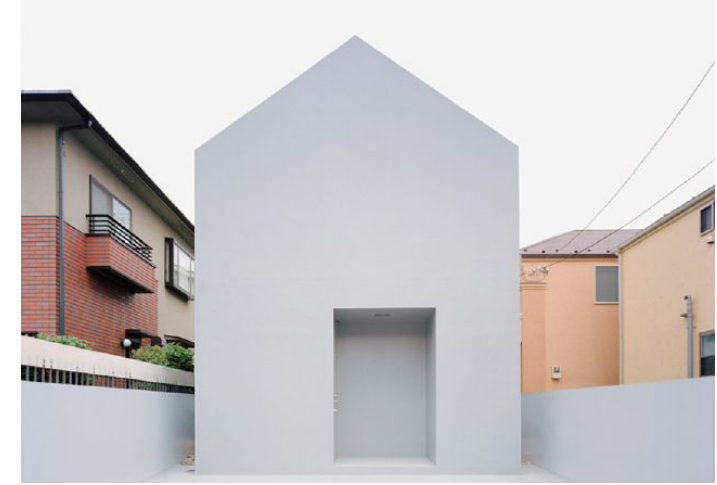

5-6. ábra: Plexi adománygyűjtő és minimalista ház

A harmadik lépésben további kontextusok vonhatók be a vizsgálatba. Fontosnak tartottam azt, hogy a különböző kontextusok - például az alkotó műtárgymagyarázata, egy művészettörténész alkotáshoz kapcsolódó kritikája, tematikailag, vagy technikailag rokon mütárgyak - külön is láthatóvá váljanak, ezekben ugyanis az alkotás más értelmet nyerhet. Újabb kontextusként az alkotó mütárgymagyarázatát használtam az elemzés során, így Baglyas Erika egyéni gondolkodását vetettem össze az első és második lépésben megfogalmazott általános jelentéssel. A harmadik fázis izgalmas lehet azok számára, akiket érdekel a művészettörténet, mert a vizsgálat részét már nemcsak a tárgy, hanem maguk a művészettörténeti dokumentumok is jelentik. Az elemzés célját a használt kontextus típusa is meghatározza. A dolgozatban arra törekedtem, hogy az elemzési módszer segítségével rámutassak az ugyanahhoz a tárgyhoz kapcsolódó univerzális és egyéni metaforák és metonímiák közötti különbségekre.

\section{Baglyas Erika interpretációja: „Jó elöre gondoljon a jövőjére!’, 2013.}

A harmadik lépésben az intuitív elemzés módszerével vizsgáltam Baglyas Erika mütárgymagyarázatát a kognitív pszichológiai folyamat tükrében (7. táblázat). A szerző magyarázó szövegének mondatait számokkal jelöltem, így az idézett részletek mögötti zárójelbe tett számok azt jelzik, hogy hányadik mondatban található a kifejezés (l. függelék).

Elöször meghatároztam, hogy az alkotó milyen figurákat és tárgyakat említ az első mentális reprezentációjával, az „adományozással” össze- 
A kortárs képelemzés kognitív szempontú megközelítése

függésben: ezek a „pénz”, a „gyüjtődoboz” (1), a "gyerek méretü ház” (9), a „kéményen keresztül” (9), valamint a „kordon” (19). Ezután listázom az „adományozáshoz” kapcsolódó akciókat és eseményeket. Az érzékelhető tartalmakkal („adományozás") egy időben fejti ki a nem érzékelhető tartalmak összefüggésrendszerét az „együttérzés”, a „mások megsegítése”, az „önkéntesség” keretek összekapcsolásával. A percepció és az appercepció folyamatai szorosan összekapcsolódnak, nem lineárisan követik egymást, hanem folyamatos visszacsatolásról van szó. Erre építenek a kiállítási falfeliratok is, amik rendszerint arra késztetik a nézőt, hogy egy-egy informatív sor elolvasása után visszatekintsen a képre. A percepció során Baglyas olvasatában a perselyhasználat révén megtapasztalható a gyüjtőpersely ház alakja, aminek szükségszerüen tartály, vagy doboz kiterjedése van.

$\mathrm{Az}$ appercepció részeként az alkotó nem érzékelheto” tartalmakat (például „együttérzés”) kapcsol az érzékelhető tartalmakhoz („adományozás”). Baglyas magyarázata szerint „az önkéntesség és a pénzadományozás a másokkal [...] való együttérzés kimutatásának egy modern formája" (3) révén a következő egyéni fogalmi metafora jön létre: AZ EGYÜTTÉRZÉS KIMUTATÁSÁNAK MODERN FORMÁJA AZ ÖNKÉNTESSÉG ÉS AZ ADOMÁNYOZÁs. Az alkotó értelmezésében a korábban megfogalmazott A SEGíTSÉGNYÚJTÁs ADOMÁNYOZÁs metafora egy speciális, egyéni változata érvényesül, amelyben az ÉRZELEM (AZ EGYÜTTÉRZÉS) a céltartomány, a CSELEKVÉS pedig a forrástartomány. A metafora az EMOTIONs ARE FORCES (AZ ÉRZELMEK ERŐK), aZ EMOTION IS MOTION (AZ ÉRZELEM MOZGÁS/CSELEKEDET) és aZ EFFECT ON EMOTIONAL SELF IS CONTACT WITH PHYSICAL SELF (AZ ÉRZELMI HATÁS FIZIKAI KONTAKTUS) metaforákon alapul (Lakoff, 1991. 141.o.). Az együttérzés absztrakt fogalom, amit Baglyas „kényszerítő erőként” definiál (1), ami arra készteti az embert, hogy lelkiismeretét megkönnyítve elővegye a pénztárcáját és bedobjon egy érmét a perselybe.

Az alkotó elkezdi újrastrukturálni az „adományozás" keretet, amikor összehasonlítja a vagyonosodást és a támogatási hajlamot, és összeveti a múltbeli lokális segítségnyújtást az elidegenedett modern kori támogatási formával. A pszichológiai folyamatok boncolgatása révén konstruálja meg a VÁGYOTT ÉLET ELÉRÉSE (cél) A HÁz MEGSZERZÉSE (forrás) fogalmi metaforát: „a vágy, hogy házat szerezzünk magunknak..." (22). Ez láthatóan megegyezik azzal a metaforával, amit a banki reklám asszociációit előhívó cím generált: A JOBB JÖvŐ/A BOLDOGABB ÉLET A HÁz MEGSZERZÉSE. Az egyéni metafora olyan fogalmi metonímiákon alapul, amiket a ház forma és a ház mérete működtet. Ezek ugyanis Kádár kori gyerekjátékokat idéznek: a forma előhívja a kutyás perselyt, a méret pedig a lemosható nejlon játszóházat (7-8. ábra). Ezek a középiskolások számára, valószínűleg a generációs különbség miatt, ismeretlenek voltak, hiszen a Kádár-korhoz való viszonyuk pusztán történeti, miközben Baglyas Erika gyerekként megélte azt, és maga is használta ezeket a játékokat. Szintén rejtve maradt az alkotónak az a gondolata, hogy a ház gyerekmérete a használhatatlanságot, a nonfunkcionalitást erősítve a fogyasztói társadalom kritikája. A Kádár-korszak szocialista berendezkedésének megidézése a gyerekjátékokkal és a szabadpiaci kapitalizmus, valamint a globalizmus reprezentációja az adományozás módján keresztül feszültséget teremt. Az egyik a múlt örökségét, míg a másik a modern kor és a fogyasztói társadalom gondolkodásmódját tükrözi.
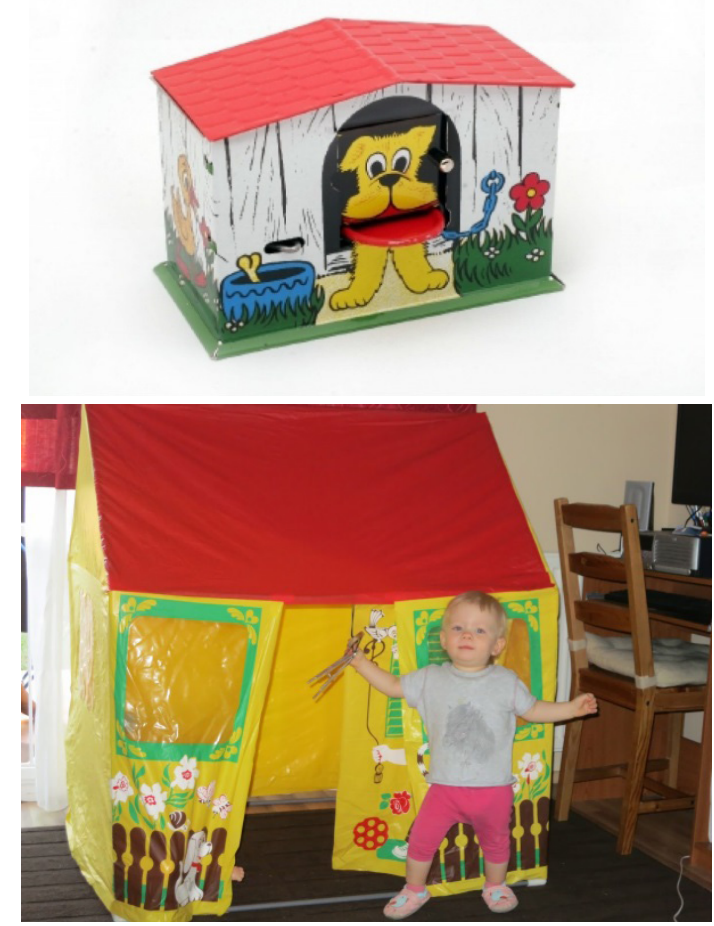

7-8. ábra: Kutyás persely és lemosható műanyag játszóház 
Virág Ágnes

A feszültség a múlt és a jelen ellentéte helyett, a jelenben tovább élő múlt felé tolódik el, amit a gyerekjátékok mechanizmusaira épülő automatikus gondolkodás is megerősít. Ezt az idősíkok közötti folyamatosságot hangsúlyozza Baglyas akkor is, amikor a jelen és a jövő közötti összefüggéseket vizsgálja. A vÁGYOTT ÉLET ELÉRÉSE A HÁZ MEGSZERZÉSE verbális fogalmi metaforában a két tartomány - a boldogságra való törekvés és a vagyonszerzés - hasonló szerkezetre épül. Mindkettő a jelenből a jövő felé tartó, célorientált aktus, ami eszköztárában a múltat követi. A metaforában a jelenben vágyakozó személy a megtakarítással rendelkező alannyal azonosítható, aki a jövőben valószínűleg boldog személy, vagyis háztulajdonos lesz. A középiskolásoknál is megjelent az újrastrukturált mentális reprezentáció, a „megtakarítás”, de ők a banki reklámok konnotációján keresztül jutottak erre a következtetésre. Bár Baglyas is megjegyzi a reklámokat, ő egy újabb régi játékkal áll elö, mégpedig a Gazdálkodj okosan! táblajátékkal (9. ábra), amely generációk óta gyakoroltatja a magyar gyerekekkel a telekkarton megszerzését, a gépkocsi nyereménybetétkönyv, a víkendház és az elérhetetlen külföldi út összefüggésrendszerét. A középiskolások számára természetes módon már nem jelent aktív jelentéshálózatot a Casco, az Épület- és Háztartási Biztosítás, az SZTK, az IBUSZ, vagy az olyan nyaralóhelyek, mint a Pilis, vagy a Börzsöny.

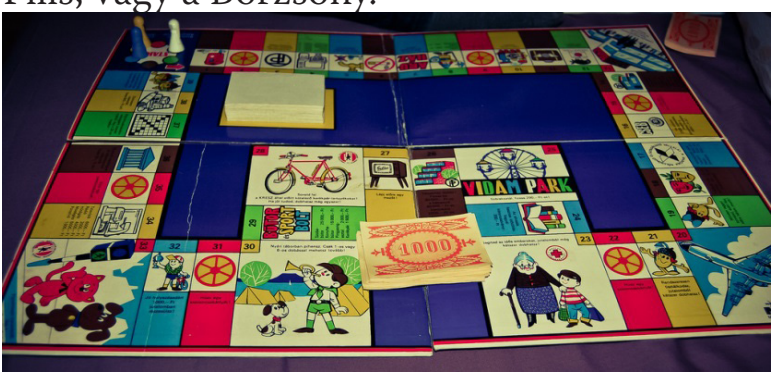

9. ábra: Gazdálkodj okosan! táblajáték

Baglyas Erika metaforikus úton határozza meg a boldogságot, ami tulajdonképpen a jövő, de kiderül, hogy A JÖvŐ CSAK ELMÉLET (24). Az alkotó megállapítja, hogy ha a cél elérésnek eszköze a megtakarítás, amit régi gyerekjátékaink alapján a valóságban is alkal-

mazunk, akkor A JELEN A BOLDOGSÁGTÓL ÉS AZ ÖRÖMÖKTŐL VALÓ MEGFOSZTOTTSÁG. A műalkotás jellemzően nem ad válaszokat és nem jelöl ki követendő mintákat. A müvész nem tanácsolja sem azt, hogy adakozzunk, sem azt, hogy költekezzünk, de azt sem mondja, hogy takarítsunk meg, vagy élvezzük a jelent. Inkább arra készteti a szemlélőt, hogy egy egyszerü ház láttán és a pénz fogalmán keresztül különböző ideológiai rendszereket és idősíkokat vessünk össze.

A háttérben meghúzódó fogalmi metafora, AZ ÉLET KERESKEDELMI TRANZAKCIÓK SORA érvényesült a diákok megfogalmazásában és az egyéni alkotói értelmezés során. A segítségnyújtást és a jobb jövőt, a boldogabb életet is a pénzzel hozták összefüggésbe. Aktívak voltak az „adományozás” és a „megtakarítás” keretek, amelyek újabb specifikus metaforák és metonímiák megfogalmazásához vezettek. Az együttérzés és a boldogabb jövőre irányuló vágyak más forrástartományokon keresztül is kifejezhetők (például kézfogás, ölelés), de az installáció a pénzhez kapcsolódó kereteket aktiválja. Hasonlóan kereskedelmi tranzakcióként értelmezzük kapcsolatainkat, amikor azt mondjuk, „hasznára válik a beszélgetés”, vagy „energiát fektet abba, hogy a kapcsolatot visszahúzza a csőd széléről". Nem a fogalmi metafora, hanem annak kidolgozása újszerű és kreatív. Az alkotói értelmezés ismerete nélkül is létrehozhatunk nagyon hasonló metaforákat és metonímiákat globális és lokális ismereteinkre hagyatkozva. A művész azonban áthelyezi a fókuszt a történetiségre, a jelenben tovább élő múltra, így Baglyas metaforái a régi gyerekjátékokhoz és azok ideológiai hátteréhez kapcsolódnak a metonimikus alapokon keresztül. Nem meglepő ez annak ismeretében, hogy a müvész DLA dolgozata, kutatási területe a hétköznapi társadalmi traumákkal, a Kádár kori cenzúrázott elmével foglalkozik (http://baglyaserika. blogspot.hu/p/sketch.html). 
A kortárs képelemzés kognitív szempontú megközelítése

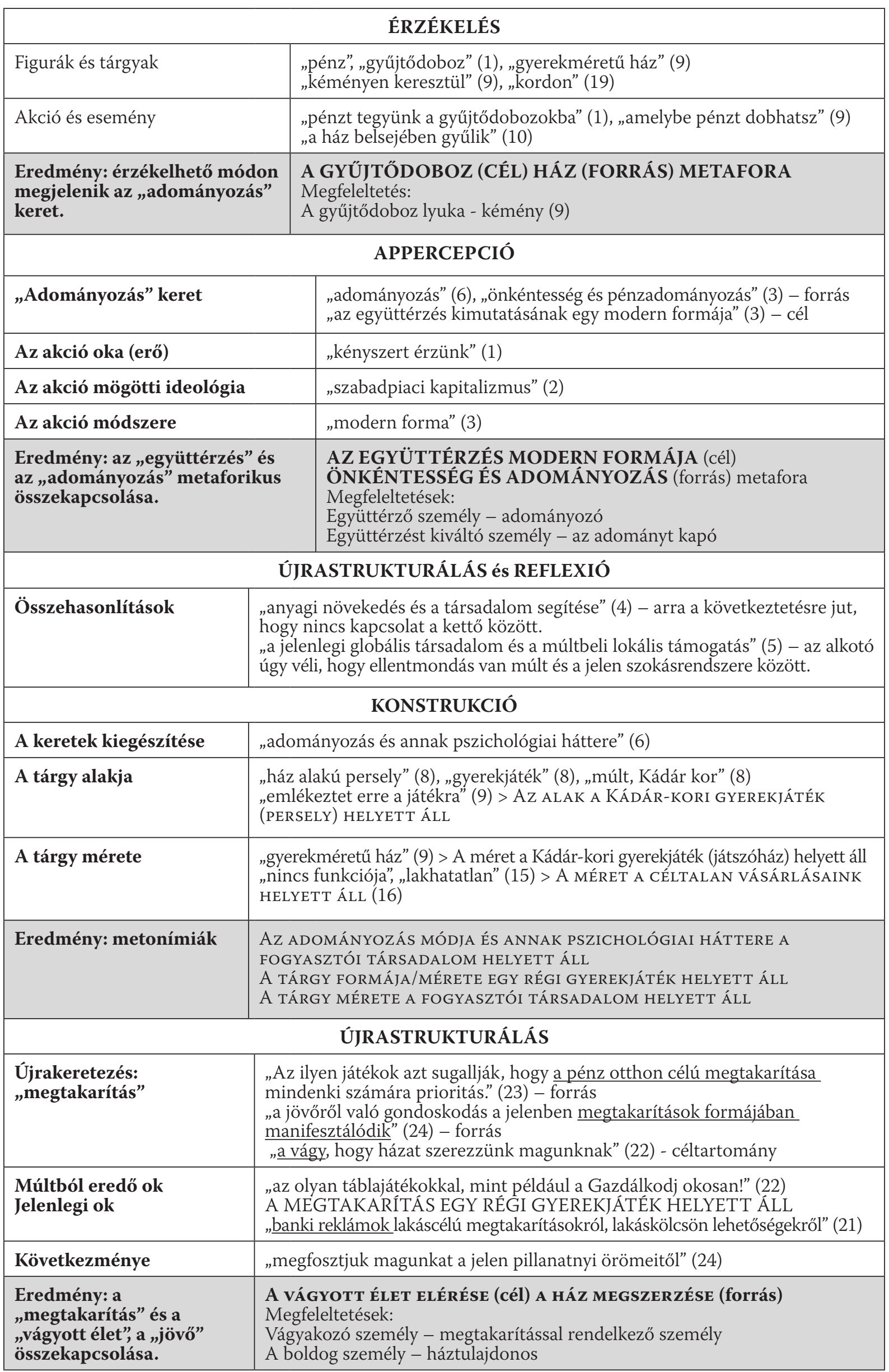

7. táblázat: Baglyas Erika mütárgymagyarázatának elemzése 


\section{Összegzés}

Mire alkalmas a kognitív szempontú elemzési módszer? Először is a módszerrel vizsgálható az emberi gondolkodás, bármely módban valósul meg. Célom volt a vizuális és a verbális tartalmak együttes kezelése, ami a művészettörténetben (Panofsky, Kuuva) és a multimodalitással foglalkozó kutatók (Forceville) körében is megjelenik. Az elemzésben láthatóvá vált, hogy a vizuális és a verbális módok hogyan kapcsolódnak egymáshoz. Például a persely a vizuális jellemzők, az átlátszó alap, a pénzérmék miatt értelmezhető. Ez aktiválja az „adományozás” keretet, aminek kifejtését a kordonon lévő feliratok segítik. A szemlélő így fedezi fel és gondolja tovább a „szegények a gazdagokért” ellentétet.

Másrészt a módszer segítségével leírhatók az elvont értelmező folyamatok. Elsősorban nem új jelentéseket kreálunk, vagy fedezünk fel, hanem a természetes módon létrejövő, szinte automatikusan kialakuló jelentéseket indokoljuk meg. Baglyas Erika installációjának elemzésével szemléltettem azt, hogyan jön létre A BOLDOGABB ÉLET/JOBB JÖVŐ A HÁZ MEGSZERZÉSE fogalmi metafora. Lehet, hogy ezt természetes folyamatnak érezzük, de valójában komplex gondolkodásmód kell ahhoz, hogy akár hétköznapi fogalmi metaforákat alkossunk meg. Ha a tartályszerü formát nem érzékelnénk, akkor A PERSELY HÁZ monomodális metaforát nem tudnánk létrehozni, ekkor pedig az „adományozás” és a „megtakarítás” keretek aktiválása is kétséges lenne. Ha a ház szimbolikus alapjelentésével nem lennénk tisztában, akkor nem tudnánk összekapcsolni a házat és a megtakarítást, hiszen alapvetően az ember nem a ház megszerzéséért, hanem a boldogsága eléréséért tesz félre. A jelentésalkotói folyamatban a már létrejött keretek nem törlődnek el teljesen akkor sem, ha újabb mentális reprezentáció jön létre, hiszen a vizuálisan és verbálisan érzékelt dolgok nem változnak meg teljesen (például A PERSELY HÁz monomodális metafora akkor is megmarad, amikor "megtakarításról” beszélünk „adományozás” helyett).
Harmadrészt arra törekedtem, hogy újabb kontextus (például az alkotó értelmezésének) bevonásával a módszer művészettörténészek számára is alkalmazható legyen. Baglyas Erika mütárgymagyarázatának elemzése rámutatott arra, hogy a PERSELY HÁz fogalmi metafora, az „adományozás” és a „megtakarítás" keretek hogyan válnak egyedivé az olyan fogalmi metaforákban mint AZ EGYÜTTÉRZÉS ÖNKÉNTESSÉG ÉS ADOMÁNYOZÁS, a VÁGYOTT ÉLET ELÉRÉSE A HÁZ MEGSZERZÉSE, illetve a megtakarítás kapcsán a JÖvő ELMÉLET, a JELEN A BOLDOG PILLANATOKTÓL VAló Megfosztottság. Baglyas mütárgyértelmezésében metonimikus úton kapcsolja össze az idősíkokat a múltban továbbélő gyerekjátékok képének konkrét vizuális és elvont fogalmi felidézésével.

A kognitív szempontú elemzési módszer nem helyettesíti a történeti célú elemző módszereket (művészettörténeti, szociológiai). Nem könnyíti meg a források gyüjtésének aprólékos munkáját, valamint nem alkalmas információtartalmú tényfeltáró munkára. A források értelmezését végezhetjük el vele, összehasonlíthatunk különböző gondolkodásmódokat. Láthatóvá teszi azt is, hogy az értelmezés hogyan jött létre az érzékelhető és a nem érzékelhető tartalmak összekapcsolása révén.

Az még kérdéses, vajon a tárgyak elemzéseit összehasonlítva leírható-e egy korszak gondolatisága egy adott fogalomra vonatkozóan. Például, ha olyan műalkotásokat hasonlítunk össze, amelyekben megjelenik a ház fogalom, akkor felfedezhető-e gondolati kapcsolat a tárgyak között. Baglyas Erika munkájához hasonlóan a ház tartályszerü, játékszerü megvalósulása több kortárs müvész alkotásában megjelenik. Ilyenek például Herbert Anikó, Panicum (2015), vagy Ferenczy Zsolt, Az én váram, az én házam (2011) című alkotásai. A Panicumban a papírházikóban egy kis papírfát látunk, az alkotó a tárgyat egy hintára tette. Az én váram, az én házam pedig a katonai gyerekjátékokat idézi fel. Megfigyeléseim alapján a szemlélő a tartály és a játék jellemzőit közvetlenül az érzékelés folyamatában felfogja, ezt továbbgondolva az 
A kortárs képelemzés kognitív szempontú megközelítése

életet gyakran játékként értelmezi. Ha a néző a házat az életcéllal azonosítja, mert úgy véli, hogy fontos dolog, a biztonság és a felnőttkor helyett áll, akkor az életet kereskedelmi tranzakcióként, a boldogságot pedig vagyonszerzésként ragadja meg. Ez történik például Zielinksi Tibor, Új pénz, új autó, új családi ház (2004) címü munkájában.

A módszer követi a műalkotás-értelmező gondolkodásmód természetességét, amit a művészeti középiskolások értelmezései is alátámasztottak. A legfontosabb eredmények, hogy szisztematikusan láthatóvá váltak a fogalmi metaforák és fogalmi metonímiák létrehozásának folyamatai, ezek globális és lokális, illetve egyéni jellemzői. Összehasonlíthatóak a hétköznapi tudáson, vagy a bővebb kontextus ismeretén alapuló kognitív folyamatok. A módszer kísérleti fázisban van, de tartalomelemzésként használhatónak tartom a vizuális oktatás bármely formájában, rajzórán, művészettörténeti, múzeumpedagógiai foglalkozáson.

\section{Felhasznált irodalom}

Beke László (2004): Müalkotások elemzése: A gimnázium I-III. osztálya számára, Nemzeti Tankönyvkiadó, Budapest.

Forceville, Ch. Lectures 1-6

URL: http://projects.chass.utoronto.ca/semiotics/ cyber/cforceville1.pdf

Forceville, Ch. (2002): The identification of target and source in pictorial metaphors, Journal of Pragmatics, 34. 1. sz., 1-14.

Forceville, Ch. és Urios-Aparisi, E. (2009): Multimodal Metaphor, Mouton de Gruyter, New York.

Forceville, Ch. (2010): Why and how study metaphor, metonymy, and other tropes in multimodal discourse?, da Silva A. S., Martins J. C., Magalhães L. \& Gonçalves M. (eds.), Comunicação, Cognição e Media I, Universidade Católica Portuguesa, Braga, 41-60.

Grady, J. (1997): Foundation of Meaning: Primary Metaphors and Primary Stress, disszertáció URL: http://escholarship.org/uc/item/ 3g9427m2
Isaeva, E. \& Mishlanova, S. (2015): Six Steps from Visual Metaphors to Visual Transfer, Mediterranean Journal of Social Sciences, 6. 6. sz., 228-230.

Lakoff, G., Espenson, J., Schwartz, A. (1991, eds.): Master Metaphor List

URL: http://araw.mede.uic.edu/ alansz/ metaphor/METAPHORLIST.pdf

Lakoff, G. \& Johnson, M. (1980): Metaphors We Live By, University of Chicago Press, Chicago.

Kress, G. \& van Leeuwen, T. 2006: Reading Images: The Grammar of Visual Design, Routledge, London.

Kuuva, S. (2007): Content-Based Approach to Experiencing Visual Art, disszertáció, Faculty of Information Technology of the University of Jyväskylä.

Kuuva, S. (2010): Symbol, Munch and Creativity: Metabolism of Visual Symbols, disszertáció, Faculty of Humanities of the University of Jyväskylä.

Panofsky, E. (1984): A jelentés a vizuális müvészetekben: Tanulmányok, Gondolat, Budapest.

Pragglejaz Group (2007): MIP: A Method for Identifying Metaphorically Used Words in Discourse, Metaphor and Symbol, 22. 1. sz., 1-39.

Šorm, E. \& Steen, G. (2013): Processing visual metaphor: A study in thinking out loud, Metaphor and the Social World, 3. 1. sz.

Steen, G. (1997): From Linguistic to Conceptual Metaphor in Five Steps, Gibbs, W.R. \& Steen, G. (eds.), Metaphor in Cognitive Linguistics: Selected Papers from the 5th International Cognitive Linguistics Conference, John Benjamins Publishing, Amsterdam, 57-77.

Steen, G. (2007): Finding Metaphor in Discourse: Pragglejaz and Beyond, Culture, Language and Representation, 4. 5. sz., 9-25.

Steen, G. (2011): From three dimensions to five steps: The value of deliberate metaphor, metaphorik.de, 10. 21. sz., 83-111.

Szabó Réka (2014): Metaforák és szimbólumok: C. G. Jung szimbólumértelmezése és a fogalmi metaforák elméletének összevetése, disszertáció.

URL: https://btk.ppke.hu/uploads/articles/ 7431/file/Szab\%C3\%B3\%20R\%C3\%A9ka_ disszert\%C3\%A1ci\%C3\%B3 


\section{Függelék}

\section{Baglyas Erika verbális mütárgy interpretációja}

Forrás: http://baglyaserika.blogspot.hu/p/ portfolio-en.html

(1) „Ma bárhol, ahol elővesszük a pénztárcánkat egy cipőboltban, egy gyógyszertárban, egy bankban - kényszert érzünk, hogy megálljunk egy pillanatra és pénzt tegyünk a gyüitődobozokba, amit a különböző segélyszervezetek helyeztek el. (2) Paradox módon ez gyakrabban történik azokban a társadalmakban, ahol szabadpiaci kapitalizmusnak volt ideje arra, hogy mélyebb gyökeret eresszen. (3) Ugyanakkor az önkéntesség és a pénzadományozás a másokkal (gyakran olyanokkal, akikről nem szükségszerüen tudjuk hol élnek a világban) való együttérzés kimutatásának egy modern formája szintén gyakoribb ezekben az országokban.

(4) Elsőre ez ellentmondásnak tűnhet: nem valakinek az anyagi növekedésén múlik a társadalom más tagjainak megsegítése? (5) Míg korábban mások megsegítésének természetes vágya a saját szűkebb környezetünk viszontagságaira fókuszált, addig ma sok civil szervezetnek globális hálózatai vannak. (6) Az adományozás és az emögött álló pszichológiai háttér formálja Baglyas Erika "Jó elöre gondoljon a jövőjére!" című installációját. (...)

(8) A műalkotás kiindulópontja egy ház alakú persely, gyerekjáték, ami majdnem minden háztartás tartozéka volt a Kádár korszakban. (9) A helyspecifikus és helyzetspecifikus installáció emlékeztet erre a játékra, miközben egy gyerek méretü ház formáját ölti, ami perselyként müködik, és amelybe pénzt dobhatsz a kéményen keresztül. (10) Az adomány a ház belsejében gyưlik, és csakúgy, mint sok más adomány esetében elöször nem tudhatjuk, hogy mire használják majd fel az összeget (eltekintve attól, hogy rögtön enyhíthetünk a lelkiismeretünkön). (11) (...) (14) A házat körülvevő kordonokra a következő feliratok kerültek: szegények a szegényekért/szegények a gazdagokért/ gazdagok a gazdagokért/gazdagok a szegényekért. (15) Maga a persely mérete arra kényszerít minket, hogy elgondolkodjunk, mi az értelme egy olyan háznak, ami nem elég nagy arra, hogy benne lakjanak. (16) Ezzel a művész reflektál olyan céltalan vásárlásainkra, amikor olyan árut szerzünk be, ami csak egy felszínes módon emlékeztet praktikus, hasznos termékre. (...)

(20) A ház alakja metaforaként is magyarázható: a bankok olyan reklámokkal árasztanak el minket, amelyek lakáscélú megtakarításokról, lakáskölcsön lehetőségekről szólnak, gyakran fiatal párokat céloznak meg. (21) A szlogen gyakran a Jó elöre gondoljon a jövőjére valamilyen variációja. (22) A vágy, hogy házat szerezzünk magunknak, már korán megjelenik a fejekben az olyan táblajátékokkal, mint például a Gazdálkodj okosan!, ami a magyarok több generációjának ismerős lehet. (23) Az ilyen játékok azt sugallják, hogy a pénz otthon célú megtakarítása mindenki számára prioritás.

(24) A jövő azonban, paradox módon csak elméletben létezik, a jövőről való gondoskodás a jelenben megtakarítások formájában manifesztálódik és abban a gesztusban, hogy megfosztjuk magunkat a jelen pillanatnyi örömeitől."

\section{Cognitive approaches to analysis of contemporary pictures}

We usually conceptualize the abstract concepts through concrete ones while watching an advertisement, or a film scene, - this process can be examined by the help of cognitive linguistic tools (Lakoff \& Johnson, 1980; Forceville \& Urios-Aparisi, 2009). I intended to prepare a methodology with cognitive aspects for analysing metaphors and metonymies appearing in human thinking about contemporary art. The method focuses on visual and verbal modalities and interprets how an art object may have more meanings. It makes meanings comparable determined by global or local context, created by universal or personal experiences. The methodology is illustrated by the analysis of an installation called 'Think about your future well in advance!' made by Erika Baglyas.

Keywords: cognitive linguistics, multimodality, content-based methodology, contemporary art

Virág Ágnes (2017): A kortárs képelemzés kognitív szempontú megközelítése. Gyermeknevelés, 5. 1. sz., $123-142$. 